\title{
High-resolution spatial distribution of greenhouse gas emissions in the residential sector
}

\author{
Olha Danylo $^{1,2}$ (D) Rostyslav Bun ${ }^{2,3} \cdot$ Linda See $^{1} \cdot$ Nadiia Charkovska $^{1}$
}

Received: 13 August 2018 / Accepted: 25 January 2019 / Published online: 25 March 2019

(C) The Author(s) 2019

\begin{abstract}
The development of high-resolution greenhouse gas (GHG) inventories is an important step towards emission reduction in different sectors. However, most of the spatially explicit approaches that have been developed to date produce outputs at a coarse resolution or do not disaggregate the data by sector. In this study, we present a methodology for assessing GHG emissions from the residential sector by settlements at a fine spatial resolution. In many countries, statistical data about fossil fuel consumption is only available at the regional or country levels. For this reason, we assess energy demand for cooking and water and space heating for each settlement, which we use as a proxy to disaggregate regional fossil fuel consumption data. As energy demand for space heating depends heavily on climatic conditions, we use the heating degree day method to account for this phenomenon. We also take the availability of energy sources and differences in consumption patterns between urban and rural areas into account. Based on the disaggregated data, we assess GHG emissions at the settlement level using country and regional specific coefficients for Poland and Ukraine, two neighboring countries with different energy usage patterns. In addition, we estimate uncertainties in the results using a Monte Carlo method, which takes uncertainties in the statistical data, calorific values, and emission factors into account. We use detailed data on natural gas consumption in Poland and biomass consumption for several regions in Ukraine to validate our approach. We also compare our results to data from the EDGAR (Emissions Database for Global Atmospheric Research), which shows high agreement in places but also demonstrates the advantage of a higher resolution GHG inventory. Overall, the results show that the approach developed here is universal and can be applied to other countries using their statistical information.
\end{abstract}

Keywords Greenhouse gas emissions · Spatial inventory · Residential sector $\cdot$ Uncertainty $\cdot$ Highresolution data $\cdot$ Geoinformation system

Electronic supplementary material The online version of this article (https://doi.org/10.1007/s11027-0199846-z) contains supplementary material, which is available to authorized users.

Olha Danylo

danylo@iiasa.ac.at

Extended author information available on the last page of the article 


\section{Introduction}

Climate change has resulted in a number of observable impacts on Earth, e.g., rising temperatures, melting ice caps, and increasing frequency and severity of extreme events (IPCC 2014). The main cause of anthropogenic climate change is the use of fossil fuels, which generate greenhouse gas (GHG) emissions. To meet the targets of the 2015 Paris climate agreement and limit the rise in global temperatures to less than $2{ }^{\circ} \mathrm{C}$, there is an urgent need for the rapid decarbonization of cities since they contribute to $70 \%$ of global GHG emissions (Solecki et al. 2018). Yet at present, national or citywide estimates of GHG emissions inform most policymaking, which are inadequate for the development of mitigation and adaptation strategies (Bai et al. 2018). Therefore, new approaches and methods are needed to provide stakeholders with additional insights for the development of national policies aiming to reduce GHG emissions in different sectors, including the residential sector.

The emissions related to fossil fuel and biomass consumption are usually calculated at an aggregate level, i.e., the total fossil fuel consumption is multiplied by emission factors and calorific values, where average values at the national or citywide levels are used based on IPCC (2006) guidelines. However, these aggregate values do not generally represent reality since the structure of fossil fuels used differs spatially for many reasons. Fossil fuel consumption is not distributed uniformly across space because it differs by area and because of the different technologies employed. Hence, more reliable and finer scale GHG emission inventories are required that take individual residences, factories, and roads into account (Bai et al. 2018). Therefore, the objective of this study is to develop a spatially explicit GHG inventory for the residential sector that can help policymakers and practitioners gain a better understanding of the spatial variability of emissions and target the implementation of new technologies in high emission areas to propose optimal strategies to local authorities for structural changes in the use of fossil fuels and the implementation of low carbon technologies. More detailed spatially explicit hybrid "bottom up"-"top down" approaches to the generation of GHG inventories will also lead to more accurate values at the citywide and national levels.

The traditional method of developing spatial inventories of GHGs is to create gridded emissions, which have historically been at resolutions of 1 to $0.25^{\circ}$ latitude/longitude (e.g., Andres et al. 2009; Rayner et al. 2010). There have been subsequent improvements to the resolution, e.g., the EDGAR (Emissions Database for Global Atmospheric Research) data set at $0.1^{\circ}(11 \mathrm{~km})$ (Janssens-Maenhout et al. 2017), $7 \mathrm{~km}$ from Kuenen et al. (2014), $1 \mathrm{~km}$ (Oda and Maksyutov 2011), and similar resolutions for regional studies (e.g., $1 \mathrm{~km}$ for Beijing and neighboring regions by Cai et al. 2018). Some approaches have involved disaggregating national GHG data using some type of proxy, e.g., nighttime lights (Ghosh et al. 2010) or road networks (Boychuk et al. 2012) while other methods have combined point source data with nighttime lights (Oda and Maksyutov 2011). Some of the gridded outputs from previous research refer only to the total GHG emissions at the global, national, and regional/local levels and hence they are not available for separate sectors (Andres et al. 2009; Rayner et al. 2010; Ghosh et al. 2010; Cai et al. 2018) or they separate only big point and non-point emission sources (Oda et al. 2018). An exception is the EDGAR (Janssens-Maenhout et al. 2017) and the residential wood combustion data set at a 7-km resolution (Denier van der Gon et al. 2015), but both are still quite coarse in terms of resolution when more detailed spatial distributions, e.g., at an urban scale, are required. 
Thus, what is currently needed are new methodologies for creating spatial inventories of GHG emissions at a finer resolution than existing products for each sector including the residential sector. Although there are many categories of human activity that cause GHG emissions, there are huge uncertainties in the estimates of emissions from the residential sector. This is due to variations in meteorological conditions across regions, the availability of energy sources, and cultural differences that lead to different demand patterns for household energy. Yet, GHG emissions from this sector are large, e.g., Levine et al. (2007) estimate that direct emissions from the residential sector are on the order of $3 \mathrm{Gt} \mathrm{CO}_{2}$-eq per year at the global scale. Other more recent estimates suggest that the residential sector is responsible for $27 \%$ of total energy consumption, which contributes to $11 \%$ of global $\mathrm{CO}_{2}$ emissions (Nejat et al. 2015). Direct $\mathrm{CO}_{2}$ emissions from the residential sector for the European Union (EU) are only slightly larger at $11.5 \%$ (EEA 2016). However, the unique feature of the residential sector is that it is possible to achieve emission reductions by either reducing direct emissions using energy from indirect sources (such as electricity) by augmentation from renewable sources or directly reducing direct emissions through modernization (e.g., through insulation of buildings) or the use of renewable energy sources by households. No other sector has such a wide potential for improvement.

The main source of GHG emissions in the residential sector is the burning of fossil fuels and biomass by households. Thus, the energy demand across all households must be estimated, which is defined as the total energy needed for cooking, water and space heating by residents, and for the purpose of keeping animals/livestock. This demand depends on factors such as behaviors related to cooking and water use, the size of the household and its energy efficiency, the living area, and the climate conditions. Energy may be supplied from centralized/public sources (such as a central hot water supply, district heating, and electricity) or from direct emissions through household energy sources such as the burning of coal, natural gas, or biomass (Jones and Kammen 2014).

Residential energy demand can be estimated directly or indirectly. Direct estimation involves obtaining consumption statistics from energy companies, the visual inspection of buildings, and the use of consumer questionnaires. The direct approach requires a considerable amount of effort and cost in data collection, especially when the analysis is performed for large areas, i.e., at the national or even global levels. Indirect estimation makes use of population density data, the spatial characteristics of the area, the climate conditions, available statistical data about household living conditions, the total living area, etc. This information is combined and used to model energy demand for each mapping unit. There has been some previous research into the development of GHG inventories in the residential sector at different levels, e.g., residential wood combustion in Europe at a 7-km grid (Denier van der Gon et al. 2015), at the regional level in Germany (Miehe et al. 2016), for 125 of the largest urbanized areas in the USA (Lee and Lee 2014), for 60 of the largest cities in India (Ahmad et al. 2015), for Salt Lake County, Utah, USA (Patarasuk et al. 2016), and for the Beijing region (Liu et al. 2016).

The aim of this paper is to develop a universal, indirect approach to the estimation of highresolution GHG emission inventories in the residential sector, and to demonstrate this approach through implementation in Poland (PL) and Ukraine (UA). They are neighboring countries with quite similar climatic conditions, they both had similar planned (non-market) economies after World War II, and the technologies and equipment used in the past and present are not modern. However, they differ from the point of view of the residential sector, i.e., the Polish economy is largely dependent on domestic coal supply, while Ukraine's economy is more reliant on natural gas with a domestic gas supply, a very well-developed transportation 
system for natural gas from Russia to Europe and a small emission coefficient for natural gas. After 1980-1990, both PL and UA moved to a market economy, which encouraged a move towards energy efficiency. PL joined the EU but then encountered problems with meeting internal obligations regarding reductions in coal use. Diversification of the national energy mix requires large investments and has led to social protests by miners. UA is trying to become self-sufficient in natural gas but the UA economy is far from energy efficient, especially in the residential sector where there is currently little household investment in building and heating system modernization or in adopting renewable energy sources. Moreover, the cost of centralized heating has become more expensive than individual heating so there has been an increase in the number of households that have converted their heating systems to biomass, resulting in higher direct emissions. Thus, both countries have different residential energy demands within a changing economic environment. The $\mathrm{CO}_{2}$ emissions from the residential sector in PL and UA are both higher than the EU at $15.0 \%$ and $13.3 \%$, respectively (OECD/IEA 2014).

The methodology outlined in this paper is a gridded approach that is based on elementary objects with homogenous population density (i.e., area-type emission sources), which are represented as polygons on a vector map. The size of elementary objects depends on how detailed the population map is. In countries with well-developed geospatial databases, these data may be available as micro-data (with certain restrictions) at the level of building blocks (e.g., in Austria), at the level of homogenous areas at resolutions of $100 \mathrm{~m}, 1 \mathrm{~km}$ or another resolution as is the case for most European countries, or at the level of settlements as is the case for Ukraine. Unlike gridded approaches, the information on the administrative assignment of each object is retained, which means that the data can be aggregated to any administrative level (even small areas such as municipalities) without losing any information or accuracy. The lowest possible level (such as a municipality) is used, where the activity data are disaggregated to elementary objects, taking into account spatial data on meteorological conditions, population density, and the availability of energy sources. The emissions by different types of fossil fuels and biomass as well as GHGs are then estimated separately. The outputs from this method are independent of any grid size (see Hogue et al. (2017) in this special issue) so can be converted to a grid of any size, for the calculation of total emissions from very diverse emission sources (i.e., point-, line-, and area-type sources in other categories of human activity). This paper complements the high-resolution spatially explicit emission inventory undertaken for the agricultural sector (see Charkovska et al. (2018) in this special issue) and for all sectors (see Bun et al. (2018) in this special issue) in Poland. These studies were conducted within the European Union FP7 Marie Curie Actions IRSES project no. 247645, acronym GESAPU.

\section{Study areas and input data}

In this study, we apply the proposed methodology to two countries: Poland, as an example of an EU country, and Ukraine as a non-EU country (Fig. 1). Poland represents a country with a well-developed statistical reporting system, where most of the data are available from online databases. Poland follows EU regulations for collecting statistical information since these data are forwarded in an aggregated form to Eurostat, the statistical office of the EU. In Ukraine, only some statistical data are available online. Enquires for data were made to all statistical departments in Ukraine at the district level but only some departments responded. Thus, data at 


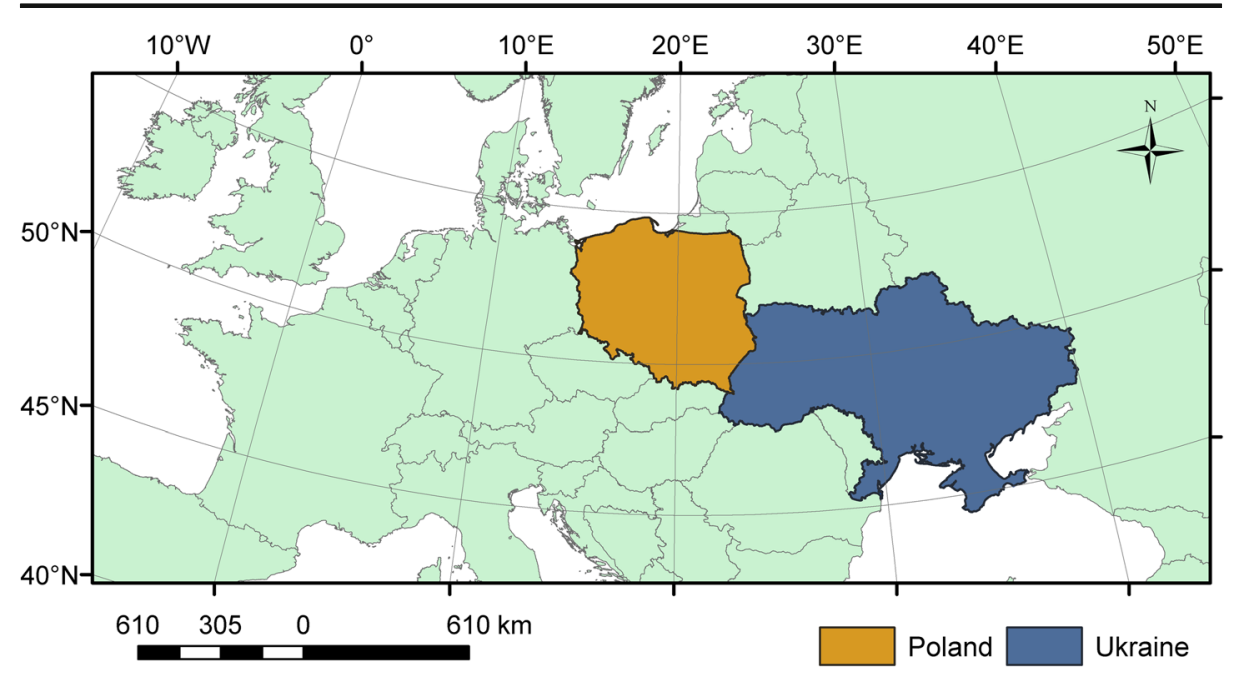

Fig. 1 Case study areas-Poland and Ukraine

the district level were used where available; otherwise, regional level data were used. The two study areas are described in more detail below, along with the input data collected and used in the analysis.

\subsection{Poland}

Poland occupies an area of $312,685 \mathrm{~km}^{2}$ and has a population of around 38.16 million for the year 2010, which makes it the ninth most populous country in Europe (Eurostat n.d.). Around $61 \%$ of the population lives in urban areas, with the remaining in rural locations. The territory of Poland is divided into 16 administrative units called voivodeships or referred to in English as region. The area of these units ranges from less than $10,000 \mathrm{~km}^{2}$ for the Opole province to more than $35,000 \mathrm{~km}^{2}$ for the Masovian region. Every region is subdivided into powiats (referred to in English as districts) with a further subdivision into gminas (or municipalities in English). Currently, there are 2478 municipalities in Poland, where 307 municipalities are urban, 1584 are rural and the remaining 588 municipalities are an urban-rural mixture.

Southern Poland is the most populated region, containing the largest conurbation in the country, which is also one of the largest in the EU, with around 2.7 million people. The Katowice urban area consists of about 40 cities and towns. However, the whole Silesian metropolitan area consists of over 50 large settlements. This metropolitan area has a population of about 5 million. The least populated regions are located in northern Poland, in particular the West Pomeranian and Warmian-Masurian regions.

According to the last national inventory report submitted to the United Nations Framework Convention on Climate Change (UNFCCC) secretariat by Poland, the total amount of GHG emissions (excluding the land use, land-use change, and forestry (LULUCF) sector) in 2010 was $402 \mathrm{Mt}$ in $\mathrm{CO}_{2}$-equivalent including $41 \mathrm{Mt}$ in the residential sector (10.2\% of total emissions) (UNFCCC 2016). Compared to the base year, the 2010 total GHG emissions in Poland decreased by $28.8 \%$ compared to $565 \mathrm{Mt}$ in the base year (1988). 


\subsection{Ukraine}

Ukraine is the largest country that is entirely situated within Europe, with a total area of around 603.63 thousand $\mathrm{km}^{2}$. The population was 45.87 million in the year 2010, making it the eighth most populous country in Europe (World Bank 2018). Around 68.7\% of the population lives in urban areas and 31.3\% in rural areas in 2010 (UkrSTAT 2017). Over one-third of the urban population is concentrated in the ten most populated cities. The territory of Ukraine is subdivided into 24 regions and the autonomous republic of Crimea, with further subdivision into districts. The two cities of Kyiv and Sevastopol have special legal status and therefore most of the statistical information for these cities is not aggregated to regional totals. The highest population density is in the Kyiv region, the Dnipropetrovs'k and Donetsk regions in Eastern Ukraine, and in the Lviv region in Western Ukraine, with greater than 110 people per $\mathrm{km}^{2}$. The lowest population density is in regions with the highest rate of forest cover, wetlands, soils with low fertility (in northern Ukraine, some regions in western Ukraine), and in the dry areas of the steppe regions in central Ukraine. Total GHG emissions in Ukraine in 2010 were slightly lower than in Poland-383 Mt in $\mathrm{CO}_{2}$-equivalent (without LULUCF), including $40 \mathrm{Mt}$ in the residential sector (10.4\% of total emissions) according to the national inventory report submitted to UNFCCC (2016). The emissions in 2010 decreased by $58.78 \%$ compared to $930 \mathrm{Mt}$ in 1990.

\subsection{Input data}

Both in Poland and Ukraine, statistical data on fossil fuel consumption in households are published at the regional or national levels (GUS 2017; UkrSTAT 2017) but only the data about natural gas consumption in Poland are available at the level of municipalities. In order to spatially disaggregate these regional totals (of activity data) to settlements as elementary area-type emission sources in our study or to a continuous spatial grid, some proxy data are needed on the following: population density; energy consumption rates; data on livestock numbers; the living area of inhabitants; heating degree days (HDD); central heating by energy source; and total living area with a central gas supply. A summary of the input data used in this study is provided in Table 1 and described in more detail below.

The energy needed for cooking in households is considered separately for families and for livestock. The former is calculated based on the population density and energy consumption rates per person. Gridded population density for Poland at a resolution of $100 \mathrm{~m}$ is available from the Joint Research Center of the EU (Gallego 2010). The data for 2000 were extracted for Poland and converted to a vector format, which were then overlaid with administrative boundaries and multiplied by the area of emission sources (settlements) and the relative change in population 2000-2010 (GUS 2017) in order to obtain a population map adapted to our GHG spatial inventory. For Ukraine, we used a map that was created from settlement coordinates and the household census for 2010 (Danylo 2015).

For livestock, energy consumption rates distinguish between livestock feed cooking (for each animal category) and water heating for drinking or sanitary needs. Data on livestock numbers per animal category are published at the district level (sheep and goats), and at the municipality level (cows, pigs, and horses) by BDL (2016). As we estimate GHG emissions on 


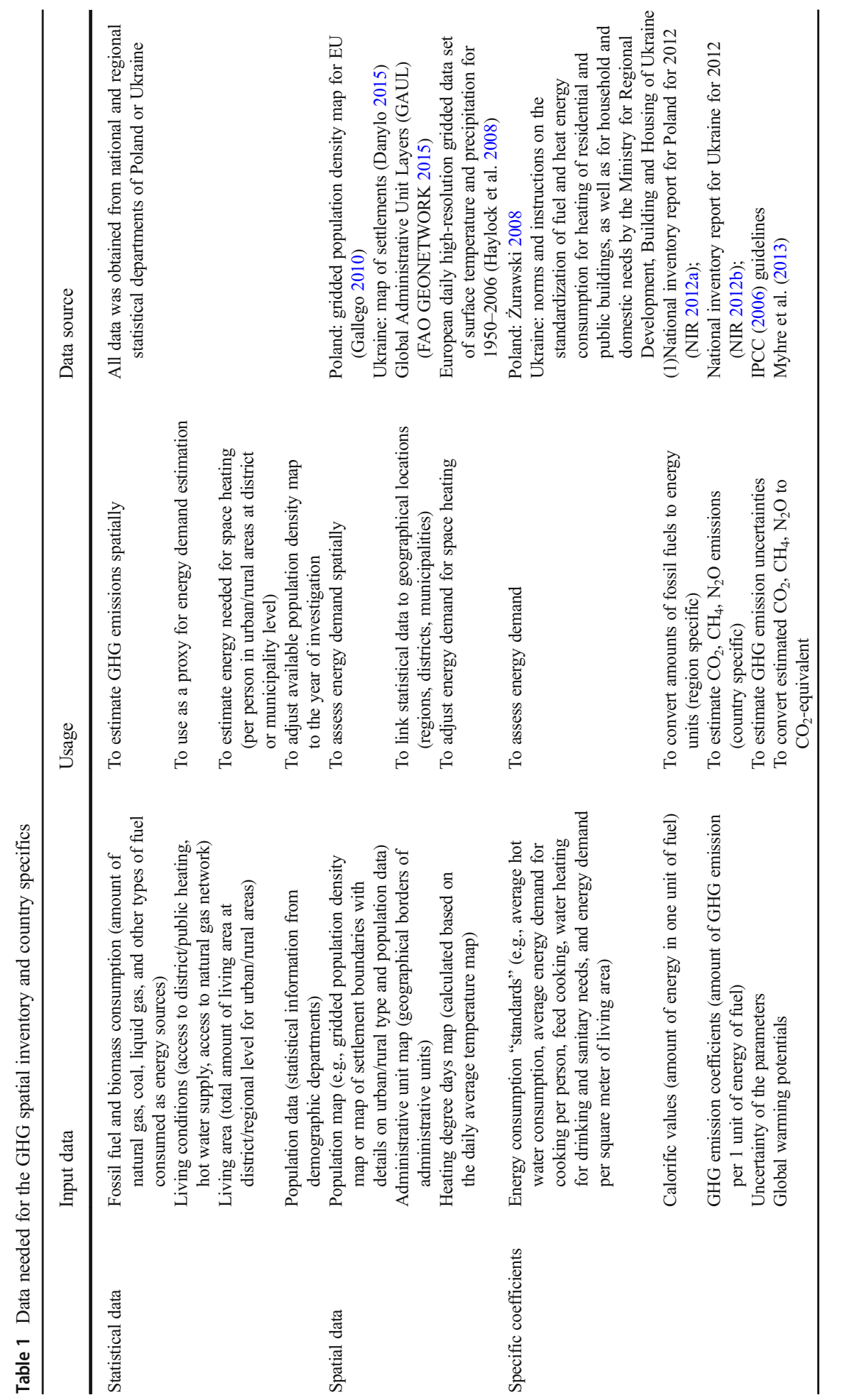


a high-resolution grid, we need to disaggregate the livestock data. There are two possible approaches: (1) the CAR method described in Charkovska et al. (2018) in this special issue, or (2) proportionally to the population density. As energy needs associated with livestock feed and cooking and water heating for drinking and sanitary needs are much lower than those related to burning fossil fuels for household energy demand, we used the second approach. Therefore, it was assumed that livestock density per $\mathrm{km}^{2}$ in rural areas is proportional to the population density within districts for sheep and goats, and within municipalities for cows, horses, and pigs. For Ukraine, livestock data are only provided by statistical departments at the regional level; therefore, these data were disaggregated proportionally to the rural population by administrative unit.

The number of HDD for Poland and Ukraine was estimated spatially using gridded data of daily temperature for Europe at a $25-\mathrm{km}$ resolution (Haylock et al. 2008). The long-term HDD average was calculated based on long-term temperature observations from the same data set (1950-2013).

Energy demand per square meter of living area $\left(Q_{h \text {,year }}^{\mathrm{sqm}}\right)$ depends on building characteristics (e.g., the number of floors, year of construction), the climatic features of a region (e.g., number of HDD), intensity of building use (e.g., working hours or the day of the week, which represents the variations in building use during the week), and heat energy losses due to entrances/exits and ventilation. For Poland, the data are available from Żurawski (2008) for several construction periods while for Ukraine the numbers were taken from norms of consumption of thermal and electric energy for Ukraine.

Information about the living area of inhabited dwellings by age of construction $\left(A_{\text {year }}\right)$ for Poland is available from the dwelling census (GUS 2017), which was conducted in 2002 at the level of districts for the following periods: before 1918, 1918-1944, 1945-1970, 1971-1978, 1979-1988, and 1989-2002 (including buildings under construction). Since these periods do not coincide exactly with the years of available data on $Q_{h \text {,year }}^{\mathrm{sqm}}$, it was assumed that the living area was constructed uniformly over each period. Since information for the years 2003-2010 is missing, this was estimated by extracting the living area constructed before 2003 from the relevant data at the beginning of 2011. For Ukraine, there is no detailed information about year of construction of the buildings. The living area of the buildings is reported as the average area per person in rural and urban areas for certain regions or districts (if provided by a specific regional department).

Data about individual central heating is available at the district level for Poland (GUS 2017) with a division into several subcategories by energy sources (i.e., electricity, solid, and gaseous fuels). These indicators were used to calculate the percentage of energy demand for space heating that is not covered from the centralized energy supply.

Natural gas consumption depends on the accessibility to the gas network. It was assumed that the energy demand for household needs that are not supplied centrally is covered by burning natural gas, whenever a gas network is available. The data about the percentage of total living area equipped with centralized gas supply was obtained from the National Statistical Office available at the level of municipality for Poland (GUS 2017).

For Ukraine, the data about access to central heating, the gas network, and hot water supplies are only available at the regional level. More detailed information can be requested from statistical departments; however, usually not all of them respond. Where the data were provided, we used information about access to central heating at the district level; otherwise, we used only regional data. In Ukraine, statistical data are reported separately for rural and urban areas, which we use in our approach. 


\section{Methodology}

To distribute the regional totals of fossil fuels to a finer spatial resolution and assess the GHG emissions, we have developed an approach for the spatial assessment of energy demand, which is used later as a proxy for activity data disaggregation. According to the IPCC guidelines, in each sector we account only for direct emissions. Therefore, emissions from electricity generation and heat production are not considered in this study. However, the approach outlined here allows for allocation of GHGs from these sectors using energy estimates from our study as a proxy.

The procedure for developing a spatial GHG inventory for the residential sector consists of the following steps (Fig. 2): (1) preparation of input data; (2) assessment of energy demand at the level of elementary geographical objects (i.e., households or settlements); (3) disaggregation of the regional data on burnt fossil fuels to the level of elementary objects using the estimated energy demand; (4) the estimation of GHG emissions spatially; and (5) visualization of results. These steps are described in more detail in the sections that follow.

\subsection{Energy demand assessment}

Energy demand is calculated at the level of settlements as the minimum mapping unit (unlike a regular grid as in traditional approaches), which is the sum of the energy needed for cooking and water and space heating. The energy needed for cooking is considered separately for families and for livestock owned by households. The former is estimated based on population density and the energy consumption rates per person. For livestock, we distinguish between the energy needed for feed cooking and water heating for drinking and sanitary needs. The average energy amounts differ by livestock type. If detailed data about the spatial distribution of livestock are not available as it is for Ukraine, then we assume that the majority of livestock is kept in rural areas and is proportional to the population density.

The estimation of energy demand for water heating distinguishes between warm and cold periods of the year, denoted respectively as $Q_{w, i}^{\mathrm{summ}}$ and $Q_{w, i}^{\mathrm{wint}}$. The estimates are based on the average energy demand for water heating per person per day $\left(N_{\mathrm{av}}^{\text {summ }}\right.$ and $\left.N_{\mathrm{av}}^{\mathrm{wint}}\right)$, which are combined with spatially resolved population data and the respective number of days in each period:

$$
\begin{gathered}
Q_{w, i}^{\mathrm{wint}}=N_{\mathrm{av}}^{\mathrm{wint}} n_{0} p_{i}, \\
Q_{w, i}^{\mathrm{summ}}=N_{\mathrm{av}}^{\mathrm{summ}}\left(n-n_{0}\right) p_{i},
\end{gathered}
$$

where $p_{i}$ is the population in an elementary object/settlement $\xi_{i}, n_{0}$ is the duration of the heating period, and $n$ is the number of days with hot water consumption, which is usually less than a full year to account for traveling and holiday. The average energy demands $N_{\mathrm{av}}^{\text {summ }}$ and $N_{\mathrm{av}}^{\text {wint }}$ are estimated as follows:

$$
N_{\mathrm{av}}^{\mathrm{wint}}=g_{\text {norm }} \cdot\left(T_{\text {hot }}-T_{\text {wint }}\right) \cdot C \text {, }
$$




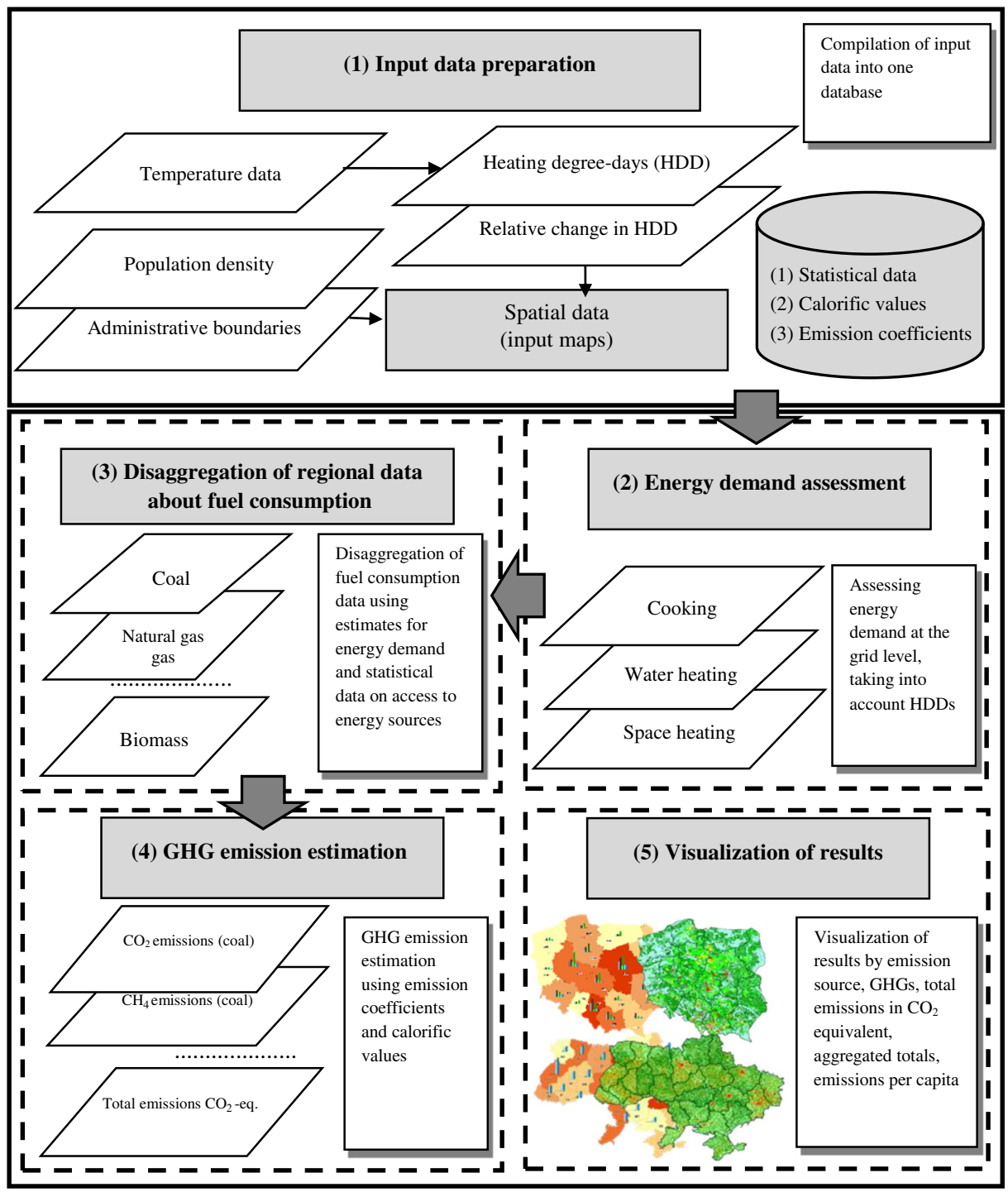

Fig. 2 Steps to assess the greenhouse gas emissions in the residential sector

$$
N_{\mathrm{av}}^{\mathrm{summ}}=g_{\mathrm{norm}} \cdot\left(T_{\mathrm{hot}}-T_{\mathrm{summ}}\right) \cdot C \cdot \beta,
$$

where $C$ is the heat capacity of the water and $T_{\text {hot }}=55^{\circ} \mathrm{C}$ is the hot water temperature. Due to the absence of reference data, a temperature for cold tap water is assumed to be $T_{\text {wint }}=5^{\circ} \mathrm{C}$ for a cold period and $T_{\text {summ }}=15^{\circ} \mathrm{C}$ for a warm period based on governmental regulations, and $\beta$ is a correction factor reflecting a decrease in the amount of water consumed during the warm period of the year. The daily norm of water consumption $\left(g_{\text {norm }}\right)$ differs depending upon the country being considered.

The total amount of energy required to provide a comfortable indoor temperature depends on the characteristics of the building (e.g., the number of floors, the year of construction), 
climatic features of the region (e.g., the number of heating degree days (HDD)), the intensity of building use (e.g., working time or day of the week), and heat energy losses due to several factors such as the number of entrances/exits and ventilation. HDD are determined based on the daily average temperatures taking into account the duration of the heating period. The total energy demand for space heating in the elementary object (i.e., area with homogeneous population density) is determined as the sum of the heat energy needed for space heating for all buildings in the settlement. This value is estimated for an elementary object $\xi_{i}$ using average indicators of heat energy needed for heating $1 \mathrm{~m}^{2}$ of living space as follows:

$$
Q_{h, i}\left(\xi_{i}\right)=k_{\mathrm{HDD}, i} \cdot \sum_{\mathrm{year}} Q_{h, \text { year }}^{\mathrm{sqm}} \cdot \mathrm{LA}_{\text {year }, i},
$$

where $Q_{h \text {,year }}^{\mathrm{sqm}}$ is the energy demand per square meter of living area constructed in the year under investigation in the elementary object $\xi_{i}, k_{\mathrm{HDD}}$ is the relative change in the amount of $\mathrm{HDD}$, and $\mathrm{LA}_{\text {year }}$ is the living area per person (square meter) in buildings that are constructed in the year under investigation.

A relative change in the number of HDD $\left(k_{\mathrm{HDD}}\right)$ characterizes how cold a heating period was in comparison to an average winter. It is estimated as the number of HDD for the year under investigation divided by the long-term HDD average. The long-term HDD average is calculated based on long-term temperature observations. Yearly HDD are the sum of the daily deviations of the mean temperature from a heating base temperature. The daily deviation of the mean temperature is calculated only for those days when the mean temperature is lower than the base temperature. The indoor temperature adequate for human comfort is $18^{\circ} \mathrm{C}$, which was assumed as a base temperature in this study (Galindo et al. 2016).

\subsection{Disaggregation of regional data on fossil fuel consumption}

In many cases, statistics on fossil fuel consumption are available at the regional or district level, particularly for the residential sector. In our study, we allocate fossil fuels as activity data in this sector proportionally to energy demand for cooking and water and space heating, taking into account the data on access to energy sources, the percentage of living area equipped with central heating, and the data on hot water supply. The amount of fossil fuel consumed of the $f$ th type ( $f \in\{$ coal, natural gas, liquid gas, biomass/wood, ... $\}$ ) in an elementary object $\xi_{i}$ is determined as:

$$
A_{i, f}=A_{r, f} \cdot d_{r, i, f}^{\mathrm{ter}}, \quad i=\overline{1, N_{r}}
$$

where $A_{r, f}$ is the amount of fossil fuel consumed of the $f$-th type in the $r$-th region; ter $\in$ urb, rur\} characterizes the affiliation of the elementary object/settlement to an urban or rural area; $r \in R$ is the set of administrative territorial units (regions); $N_{r}$ is the number of settlements in the $r$-th territorial unit; and $d_{r, i, f}^{\text {ter }}$ is the disaggregation coefficient that is defined as follows:

$$
d_{r, i, f}^{\mathrm{ter}}=\frac{k_{i, f}^{\mathrm{ter}} \cdot\left(a_{r, m, f}^{\mathrm{ter}} Q_{c, i}+b_{r, m, f}^{\mathrm{ter}} Q_{w, i}+c_{r, m, f}^{\mathrm{ter}} Q_{h, i}\right)}{\sum_{\operatorname{ter} \in\{\operatorname{urb}, \operatorname{rur}\}} \sum_{m \in M_{r}} \sum_{r \in R}\left[k_{E O, f}^{\mathrm{ter}} \cdot\left(a_{r, m, f}^{\mathrm{ter}} Q_{c, E O}+b_{r, m, f}^{\mathrm{ter}} Q_{w, E O}+c_{r, m, f}^{\mathrm{ter}} Q_{h, E O}\right)\right]},
$$

where $\xi_{i} \in S^{\text {ter }}=S_{\text {urb }} \cup S_{\text {rur }}$ is the set of elementary objects in the urban and rural areas; $a_{r, m, f}^{\text {ter }}$, $b_{r, m, f}^{\mathrm{ter}}$, and $c_{r, m, f}^{\mathrm{ter}}$ are the percentages of energy demand for cooking, water heating, and space 
heating, respectively that are not covered from the centralized energy supply in municipality $m \in M_{r} ; k_{i, f}^{\text {ter }}$ is the accessibility of the $f$-th fuel in the elementary object $\xi_{i} ; Q_{c, i}, Q_{w, i}$, and $Q_{h, i}$ are the energy demands for cooking and water and space heating, respectively, in each elementary object $\xi_{i}$; and $E O$ is the particular settlement.

The accessibility of the energy source as defined here provides insights into the amount of this type of energy used in a particular spatial location. For example, natural gas is supplied through the centralized gas network. Thus, if some settlements or districts have no access to the network, households will cover their energy needs from other sources, such as burning liquid gas, wood, or other fuels. Therefore, natural gas consumption for this settlement will be equal to zero. The higher the percentage of the living area in the settlement that has access to the gas network, the higher will be the consumption, if there are no energy sources at a lower price.

The percentages of energy demand for cooking, water heating, and space heating that are not covered from centralized energy sources are defined based on statistical data available. For energy needed for cooking, we set the coefficient to 1. Energy needed for water heating depends on what percentage of the population has access to a centralized hot water supply, and the amount of energy needed for space heating depends on what percentage of houses are connected to the centralized heating network. This statistical data are available at the district level separately for urban and rural areas for most regions in Ukraine. In Poland, they are available at the municipality level.

The disaggregation coefficients for each of the sources of fossil fuel consumption will add up to 1 for all elementary objects within a region as follows:

$$
\sum_{\text {ter } \in\{\text { urb,rur }\}} \sum_{i \in M_{r}} \sum_{r \in R} d_{r, i, f}^{\text {ter }}=1, \quad f \in\{\text { coal, wood, } \ldots\}
$$

This approach makes it possible to compute the activity data for each area-type emission source (settlement) based on known statistics at the provincial level, and taking into account some spatial proxy data such as urban and rural areas, the accessibility of each type of fuel, and the percentages of energy demand for cooking, water heating, and space heating, which are not covered from the public energy supply.

\subsection{Estimation of GHG emissions}

We estimate emissions of the $g$-th GHG from burning fossil fuel of the $f$-th type in each elementary object $\xi_{i}$, using disaggregated activity data about fossil fuel consumption $\left(A_{i, f}\right)$ as follows:

$$
E_{i, f}^{g}=A_{i, f} \cdot E F_{i, f}^{g},
$$

where $E F_{i, f}^{g}$ is the emission factor of the $g$-th GHG for the $f$-th type of fuel in the $\xi_{i}$ settlement, i.e., this parameter is not the same for all area-type emission sources because fuel characteristics differ depending on the production basin, the equipment used, etc. The total emissions for each administrative unit $Z$ (municipality, district, or region) are calculated in $\mathrm{CO}_{2}$-equivalents using the global warming potential (GWP) of each GHG as expressed below:

$$
E_{Z}^{\text {total }}=\sum_{g \in\left\{\mathrm{CO}_{2}, \mathrm{CH}_{4}, \mathrm{~N}_{2} \mathrm{O}\right\}} \mathrm{GWP}_{g} \sum_{f \in F} \sum_{i \in Z} E_{i, f}^{g},
$$

where $F$ is a set of fuel types that are used in an administrative unit. 


\section{Results}

\subsection{GHG emissions in the residential sector}

\subsubsection{Poland}

Figure 3 shows the results of the spatial inventory of GHG emissions in the residential sector for Poland, where the largest GHG emissions can be observed in Polish cities, especially in Southern Poland (see the full results in Supplementary Materials).

The largest specific emissions (per $\mathrm{km}^{2}$ ) are observed in Katowice and nearby areas, which are part of the Katowice conurbation (SLK) as well as in Warsaw (MAZ). The large cities in every region are represented by high emissions, mostly due to the high population density and the significant share of emissions from burning coal and biomass. According to the report on the state of forests in Poland (2012), specific emissions in the Lubusz (LBU) region are low as this region has the highest forest cover (49.1\% of area) and a low population density. In terms of emission per capita, the Lubusz region is characterized by the lowest emissions ( $0.99 \mathrm{t} /$ capita) compared to other regions, mainly due to better access to the natural gas supply network and a higher share of energy covered from this source. The largest emissions per capita are in the WKP and MAZ regions (1.63 t/capita in both regions). This is mostly due to coal and biomass being the main energy source used in these regions.

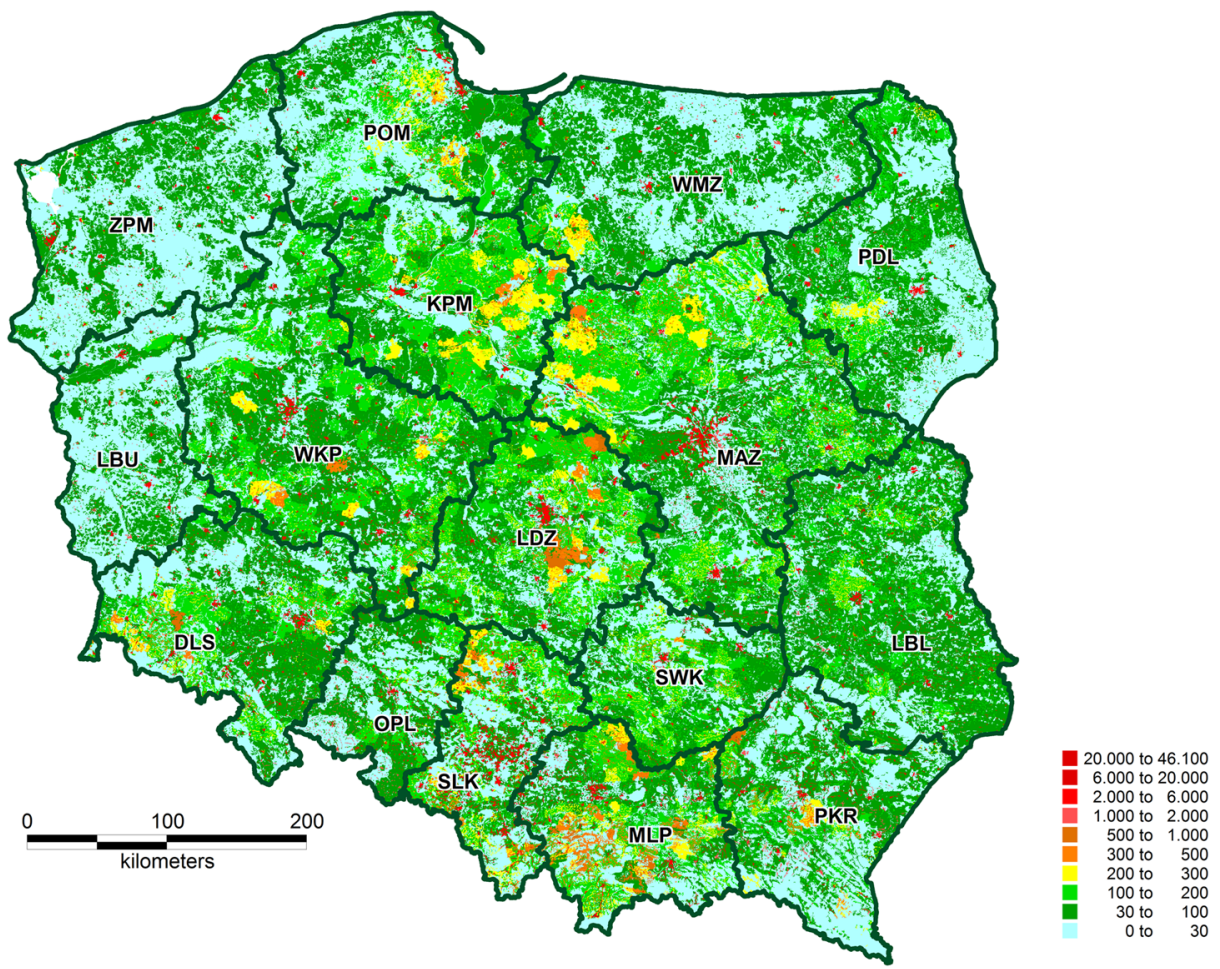

Fig. 3 Specific total GHG emissions in the residential sector including biomass (level of emission sources, $\mathrm{t} / \mathrm{km}^{2}$, $\mathrm{CO}_{2}$-eq, Poland, 2010) 
The results are presented as specific emissions in $\mathrm{CO}_{2}$-equivalent (Fig. 3) and total emissions by fuel type (Fig. 4); however, the detailed structure of GHG emissions can be further explored by fuel type and GHG.

\subsubsection{Ukraine}

Figure 5 shows the results of the spatial inventory of GHG emissions in the residential sector for Ukraine where the results show that more than $33.2 \%$ of GHGs are emitted in four regions: the Donetsk, Kyiv, Dnipropetrovs'k, and Luhans'k regions. The structure in GHG emission sources differs across the country and depends on the availability of energy sources.

Natural gas is the main energy source in Ukraine, which provides almost $42.1 \%$ of all energy. The production and processing of natural gas in the country is high as well as the imports from Russia. The prices are low compared to prices for other energy sources; therefore, it is heavily utilized in the steel industry, the energy production sector, and by district heating in the residential sector. As Ukraine has its own coal reserves, the total share of energy produced from this energy source in 2010 was over 28.3\% (UkrSTAT 2017). Coal together with natural gas is used for thermal power stations for heat and electricity production, as well as for the individual energy needs of the household sector, where centralized energy

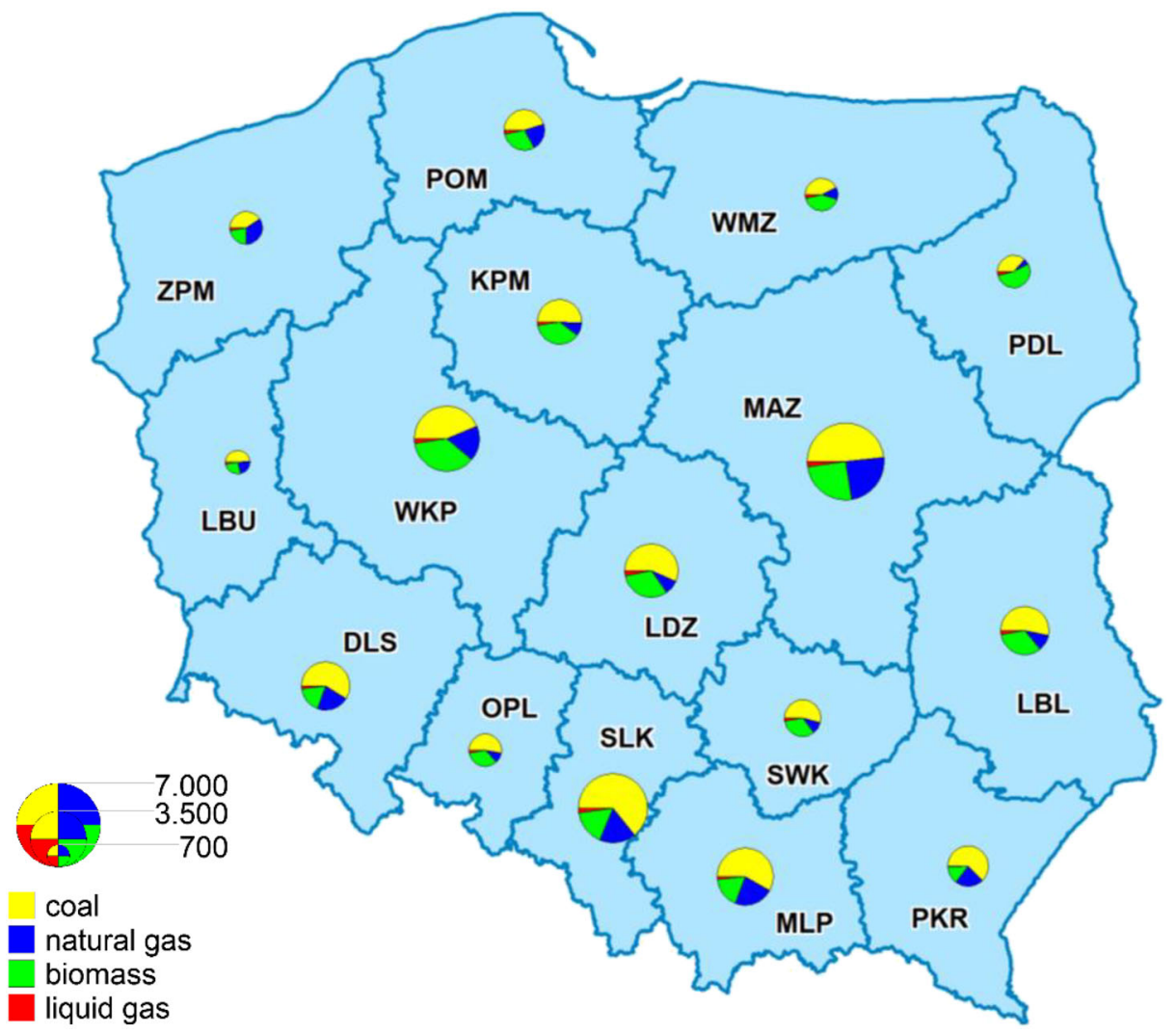

Fig. 4 GHG emission structure by fuel type at the regional level (the size of the circles represents total emissions for the region, colors represent the fuel type and the share of the total emissions, thousand tons, $\mathrm{CO}_{2}$-eq, 2010) 


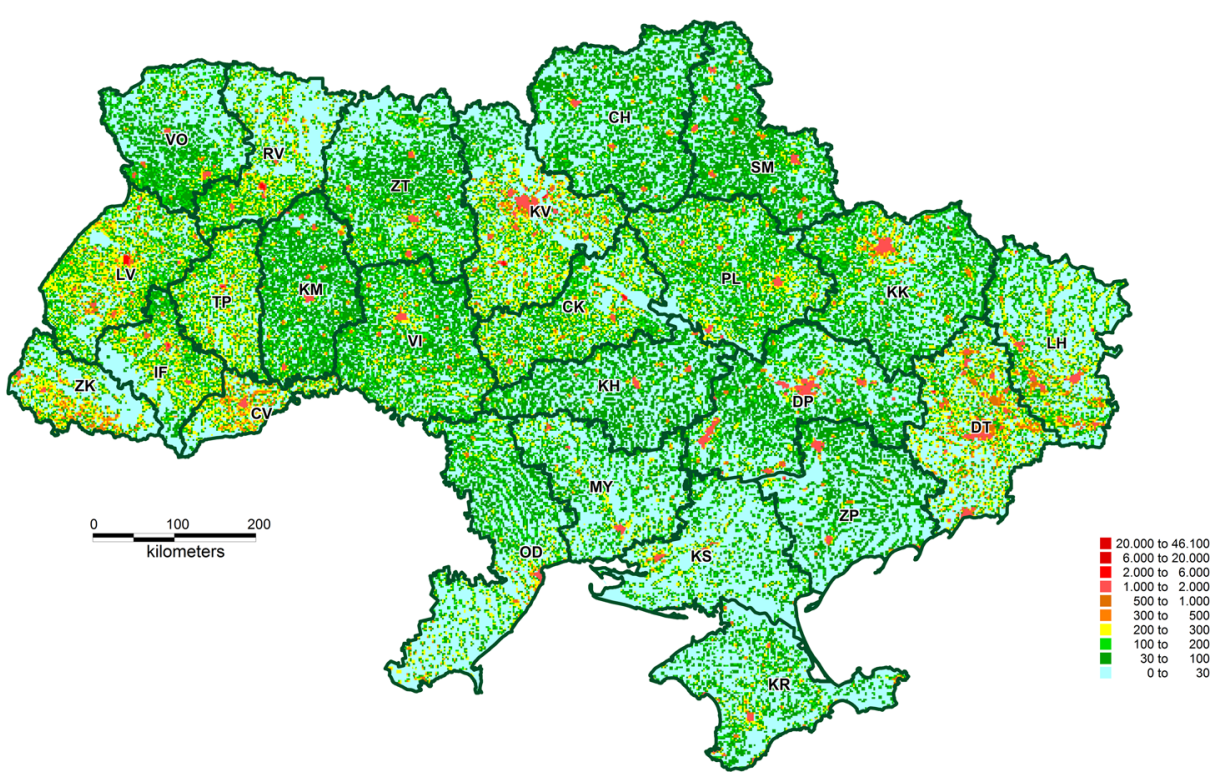

Fig. 5 Total GHG emissions in the residential sector in Ukraine including biomass $\left(2 \times 2-\mathrm{km}\right.$ grid, $\mathrm{t} / \mathrm{km}^{2}, \mathrm{CO}_{2}$ equivalent, 2010)

sources are not available. For example, as the coal mining industry is developed in Eastern Ukraine, this fossil fuel is more frequently used in the residential sector in these regions than in Western Ukraine (Fig. 6).

The large areas in the northern part of the country are covered with forest, making wood a more accessible energy source in these regions. Therefore, the percentage of GHG emissions caused by burning biomass is higher in this part of Ukraine, compared with other territories. The highest emissions are in highly populated cities.

\subsubsection{Comparison of the results for the two study areas}

As the methodology developed here is flexible in terms of the input data used, we utilized all available and relevant data for each country in terms of maps and statistical information. In order to identify differences in the final results, we compared the GHG emission inventory results for bordering regions in Poland and Ukraine. As these regions have similar climatic conditions, consequently the energy demand per capita and the specific emissions are expected to be similar. The overall patterns in specific emissions in nearborder regions are comparable (Fig. 7). The specific emissions in the Carpathian region are low in both countries, while specific emissions in large cities are at the same level in both countries. The distribution of the areas with very low emissions (below $100 \mathrm{t} / \mathrm{km}^{2}$ ) is different in both countries. In the LUB and SWI regions, the emissions in larger areas are between 50 and $100 \mathrm{t} / \mathrm{km}^{2}$ in large areas, compared to Ukraine, where in more grid cells the emissions are below $50 \mathrm{t} / \mathrm{km}^{2}$. This difference can be due to different population maps that were used for these countries as well as different spatial distributions of the population in both countries. The population density map for Poland (Gallego 2010) is based on municipality population data and land cover map, while the population map for Ukraine 


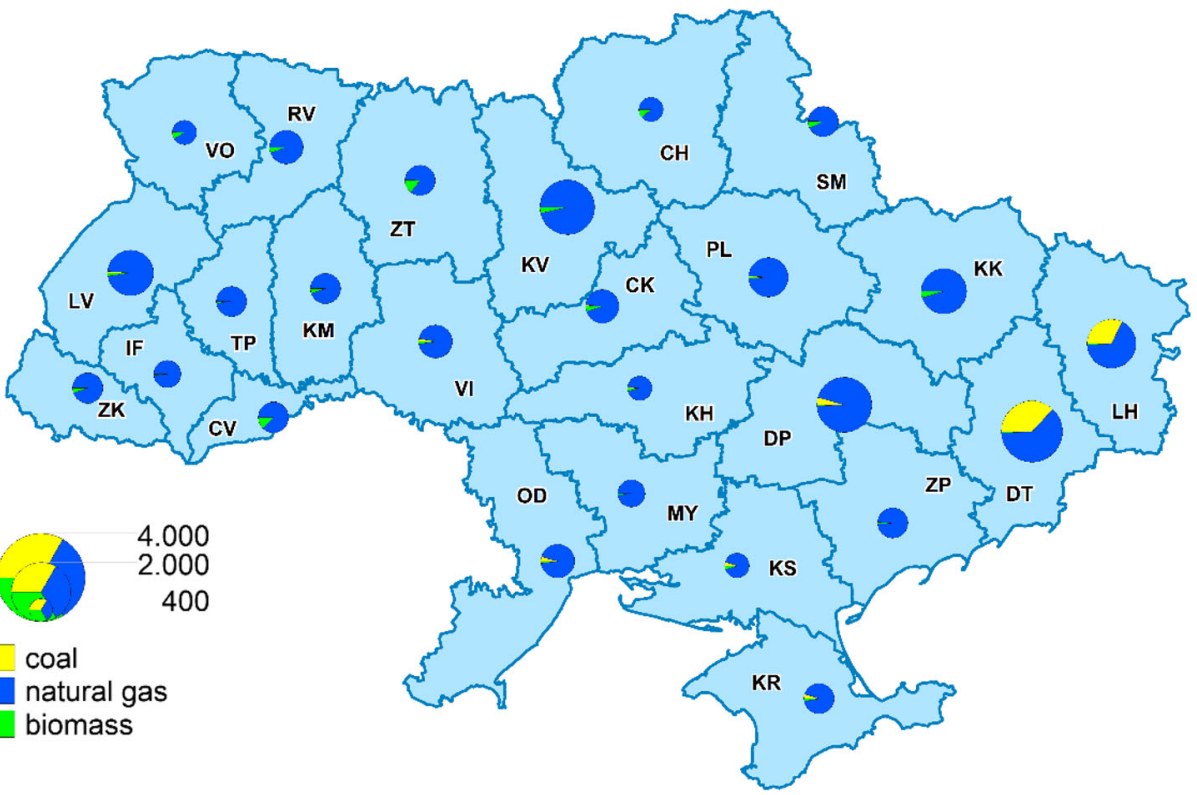

Fig. 6 GHG emission structure by fuel type at the regional level (the size of the circles represents total emissions for the region, colors represent the fuel type and the share of the total emissions, thousand tons, $\mathrm{CO}_{2}$-eq, 2010)

has been derived from detailed statistical information about population count at the settlement level for urban areas and uses district data for rural areas.

\subsection{Validation of the results}

The Polish statistical department collects data about coal and liquid gas consumption in the residential sector at the regional level and wood and coke consumption only at the national level. Only information about usage of natural gas by households is available at the municipality level, which we use not only for emission estimates but also for validation of our approach. For these reasons, we performed three main steps: (1) we aggregated the data to the regional level, (2) we disaggregated the data to the level of elementary objects using our approach, and (3) we compared values obtained here with the original statistical data.

In Ukraine, all the data about fossil fuel consumption are available either at a regional or national level. As the centralized statistical database does not contain detailed information at a finer than regional resolution, we have requested more detailed data from regional statistical departments. Only 3 out of 25 statistical departments shared data about wood consumption in the residential sector at the district level (others either did not respond or stated that the requested information is confidential). We used the data obtained for comparison with the results of the disaggregation.

\subsubsection{Poland}

The results of the validation exercise are presented in Table 2. The results show high agreement between the statistical data and the disaggregated data on natural gas consumption in the residential sector in Poland. We fit a linear model of the form "statistical data $\sim 0+$ 


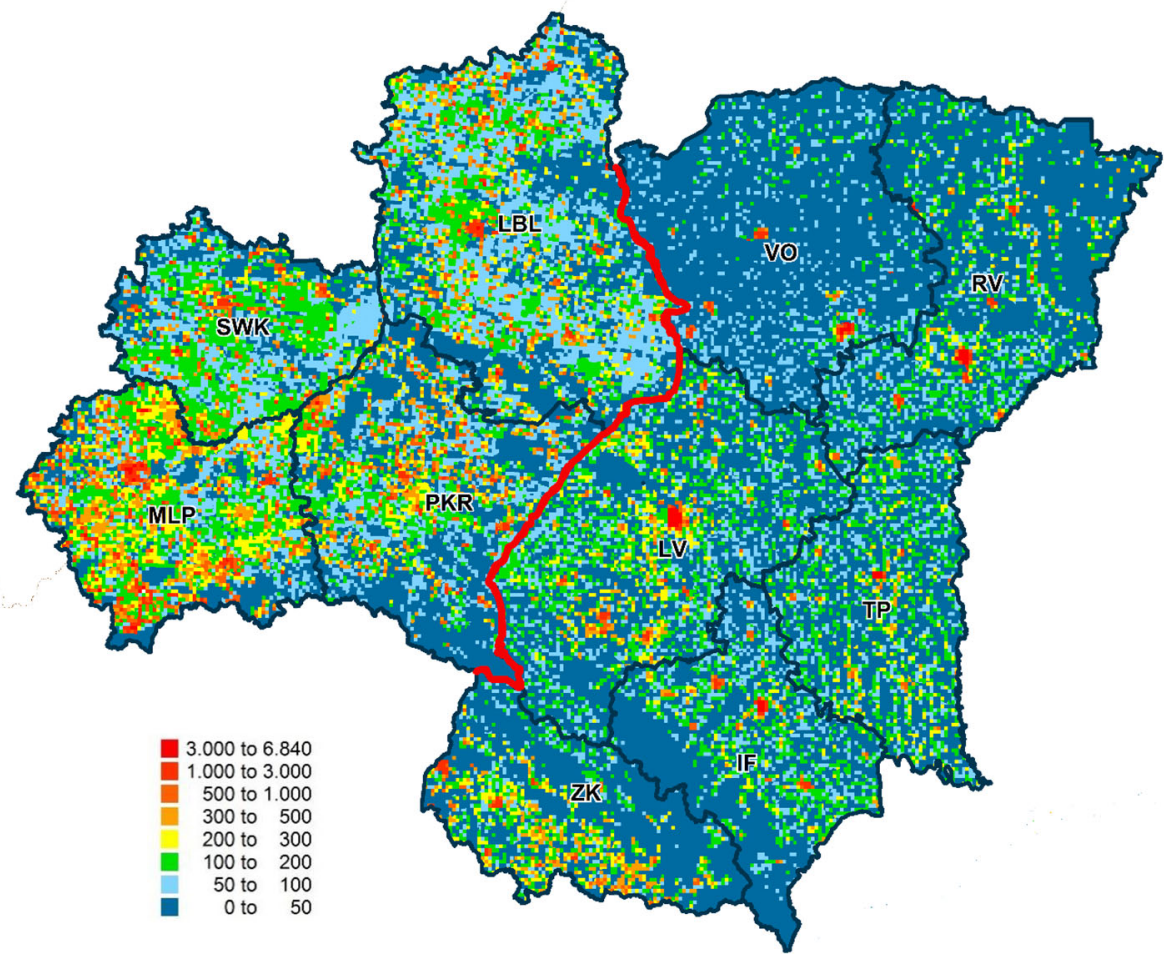

Fig. 7 Total GHG emissions in the bordering regions of eastern Poland and western Ukraine including biomass (the red line represents the border between Poland and Ukraine, $\mathrm{t} / \mathrm{km}^{2}, \mathrm{CO}_{2}$-equivalent, $2 \times 2 \mathrm{~km}, 2010$ )

disaggregated data" for each region separately for urban and rural municipalities, setting the intercept term to zero. When the model output is close to the statistical data, the slope term is close to 1 . The model fit is better for urban municipalities compared to rural or mixed (urbanrural municipalities). We use the adjusted $R^{2}$ as the criterion for judging how good our model performs, taking the degrees of freedom in the model into account. This performance measure can be between 0 and 1 ; the closer to 1 , the better is the fit.

\subsubsection{Ukraine}

In order to understand differences between the disaggregation results obtained for wood consumption and the statistical data that were available for three regions in Ukraine, we visualized the magnitude of the differences together with forest cover data from the ESACCI (European Space Agency-Climate Change Initiative) land cover map for 2010 (Defourny et al. 2016). We divided the statistical data by the disaggregated data (e.g., a value of 3 means that the reported wood according to the statistical data is three times higher than the amount produced by our model; see Figs. 8 and 9). These differences can be explained by specific details related to the Ukrainian statistics, i.e., the data are reported based not on the end-user consumption but allocated to distribution locations, which are mostly located in districts with dense forest cover (where forest cover is overlaid on the maps in Figs. 8 and 9 as black dots). These differences show that using the most detailed statistical data may not always produce accurate results due to the way in which these data are reported. Therefore, disaggregating data 
Table 2 Results of the linear regression of the "statistical data $\sim 0+$ disaggregated data" for natural gas consumption in Poland

\begin{tabular}{|c|c|c|c|c|c|c|c|}
\hline \multirow[t]{2}{*}{ Region } & \multirow[t]{2}{*}{ Abbreviation } & \multicolumn{3}{|l|}{ Urban } & \multicolumn{3}{|l|}{ Rural } \\
\hline & & Slope & $R^{2}(\operatorname{adj})$ & Count & Slope & $R^{2}(\operatorname{adj})$ & Count \\
\hline Greater Poland & WKP & 1.25 & 0.97 & 76 & 0.68 & 0.38 & 91 \\
\hline Holy Cross Province & SWK & 1.06 & 0.99 & 16 & 0.58 & 0.65 & 39 \\
\hline Kuyavia-Pomerania & KPM & 0.97 & 0.98 & 30 & 0.81 & 0.44 & 14 \\
\hline Lesser Poland & MLP & 1.17 & 0.99 & 52 & 0.69 & 0.8 & 128 \\
\hline Łódź & LDZ & 0.84 & 0.99 & 21 & 1.06 & 0.55 & 26 \\
\hline Lower Silesia & DLS & 0.91 & 1 & 71 & 1.79 & 0.57 & 53 \\
\hline Lublin & LBL & 1 & 0.99 & 31 & 0.66 & 0.64 & 75 \\
\hline Lubusz & LBU & 1.08 & 0.94 & 25 & 1.98 & 0.47 & 21 \\
\hline Masovia & MAZ & 0.95 & 1 & 60 & 1.12 & 0.93 & 105 \\
\hline Opole & OPL & 0.96 & 0.9 & 26 & 1.8 & 0.72 & 13 \\
\hline Podlaskie & PDL & 0.87 & 0.99 & 8 & 0.54 & 0.26 & 11 \\
\hline Pomerania & POM & 0.99 & 0.98 & 26 & 2.39 & 0.81 & 18 \\
\hline Silesia & SLK & 0.94 & 0.97 & 59 & 0.71 & 0.75 & 69 \\
\hline Subcarpathia & PKR & 1.34 & 0.97 & 43 & 0.65 & 0.86 & 127 \\
\hline Warmia-Masuria & WMZ & 1.07 & 0.95 & 23 & 1.12 & 0.67 & 18 \\
\hline West Pomerania & ZPM & 0.73 & 0.97 & 42 & 2.03 & 0.86 & 46 \\
\hline
\end{tabular}

from the regional level to the elementary object may give better estimates of the spatial distribution of emission sources.

\section{Comparison of results for Poland with the EDGAR global database}

The results obtained for Poland were compared to the corresponding results from the EDGAR global database (Janssens-Maenhout et al. 2017), which has a grid size of $6.7 \times 11 \mathrm{~km}$ at the latitude of Poland (Fig. 9). From this database, we used the data for the 1A4 sector according to the IPCC classification (IPCC 2006). For comparison, only those EDGAR cells that completely covered the territory of Poland were selected (Fig. 9a). The EDGAR data set contains gridded estimates for the IPCC 1A4 category, including emissions from categories 1A4a (commercial/institutional), 1A4b (residential sector), and 1A4c (agriculture/forestry/ fisheries). In our study, we focused only on emissions from the residential sector. In order to make our estimates comparable spatially with EDGAR's 1A4 data, we adjusted the original high-resolution results at the level of emission sources/polygons (Fig. 9d) by multiplying it with the scaling factor to take into account also emissions from categories $1 \mathrm{~A} 4 \mathrm{a}$ (commercial/ institutional) and 1A4c (agriculture/forestry/fisheries). Emissions from these categories are significantly lower than emissions in the residential sector, and their spatial pattern depends on the same proxy data such as meteorological conditions, population density, and availability of energy sources. Our results at the level of emission sources/polygons were then aggregated to the EDGAR grid cells using a proportional sum operation.

In general, both results reflect larger emissions in densely populated industrial territories and smaller ones in less populated areas of the northwest and northeast. EDGAR reflects larger emissions in big cities while our results demonstrate somewhat lower emissions in these cities, but larger emissions in areas where rural municipalities dominate. This can be explained as follows, since in big cities, a significant share of space and 


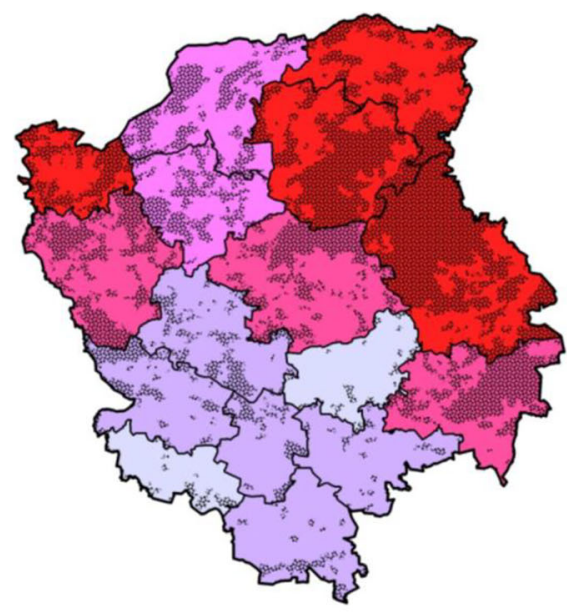

(a)

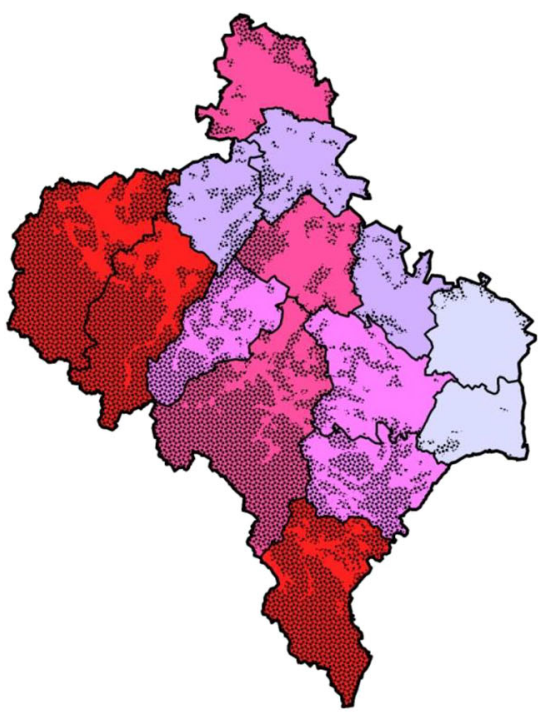

(b)

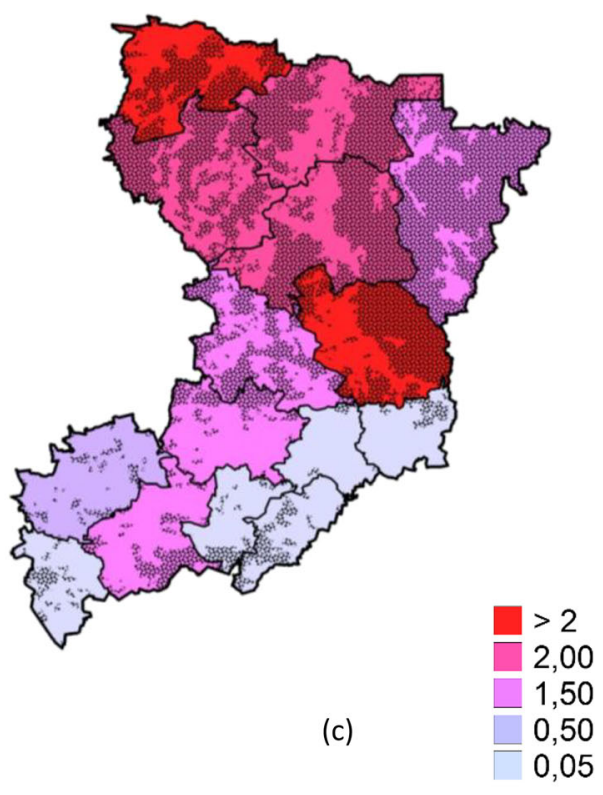

Fig. 8 Comparison of statistical data with the results of the disaggregation of wood consumption from the regional to the district level for the Volyn (a), Ivano-Frankivsk (b), and Rivne regions (c), 2010, in colors - statistical data divided by the estimated values of emissions using our modeling approach; black dots denote forest cover from the ESA-CCI land cover map

water heating energy is supplied publicly and it is counted in the emission category "public heat production" (according to the IPCC (2006) guidelines). Therefore, per capita emissions in the residential sector should be lower here. Figure 9e presents an almost uniform distribution of per capita emissions, while Fig. 9f clearly shows lower magnitudes of this parameter in big cities, but larger magnitudes in rural areas where there is no centralized heat production. This difference in per capita emissions is also observable from Table 3 , which shows that in the residential sector in large cities, a significant share of the thermal 

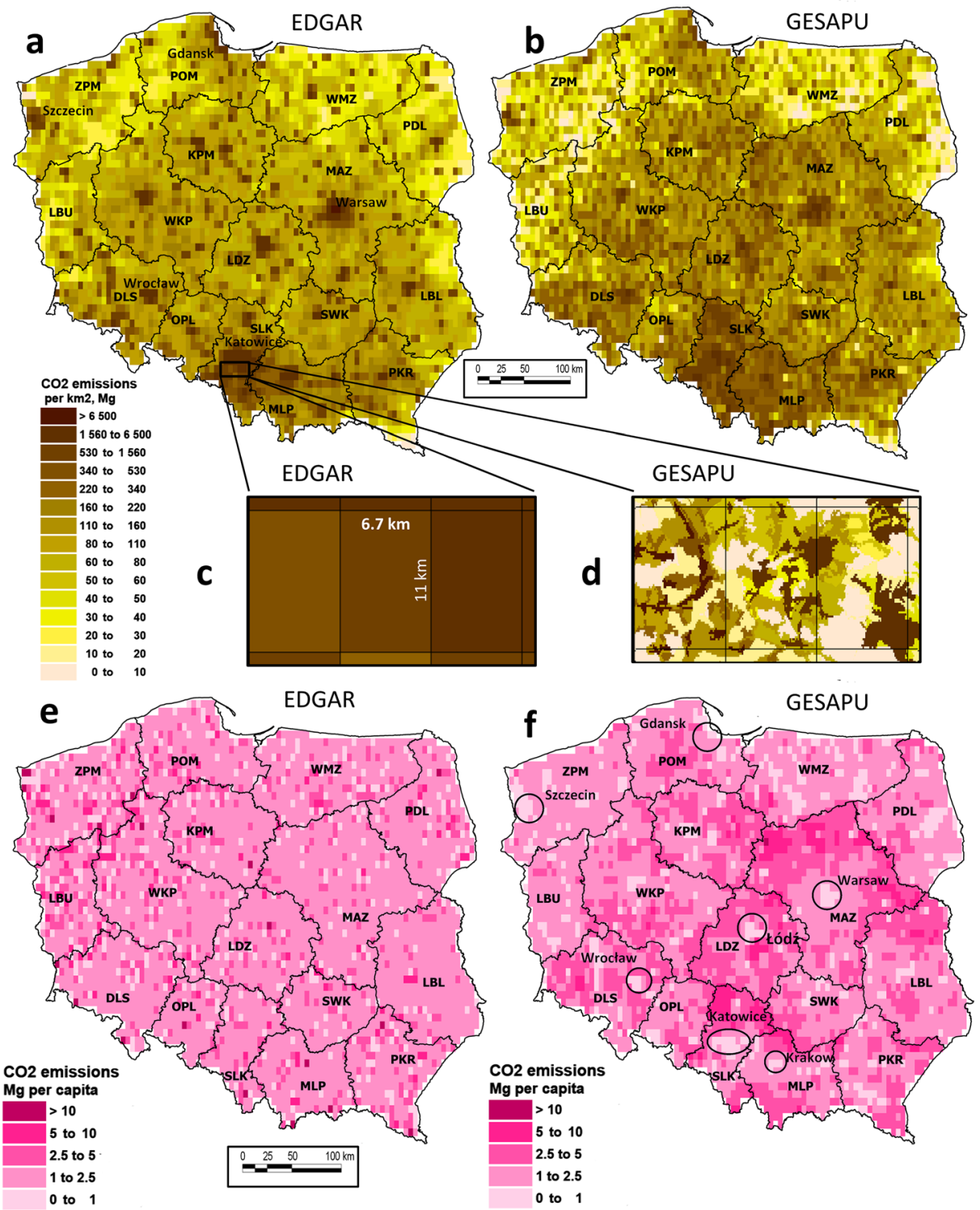

Fig. 9 Comparison of the results of the spatial analysis of $\mathrm{CO}_{2}$ emissions in the $1 \mathrm{~A} 4$ sector in Poland from the following: EDGAR (a); GESAPU aggregated to the EDGAR grid, without wood (b); an example of the original EDGAR cells in very urbanized areas of the Silesian region (c); the original polygons of the GESAPU approach in this area; e the same emissions per capita for EDGAR data (d); and GESAPU results aggregated to the EDGAR grid (Mg, 2010) (f)

energy is provided centrally; in addition, in multi-story houses, there is much less heat energy loss. Instead, this proportion increases when the results are averaged for all urban, urban-rural, and rural municipalities.

Our approach also provides the possibility to analyze the structure of emissions by major types of fuel (Fig. 10). For each fuel, the spatial pattern of emissions is significantly different due to the availability of certain types of fuel and other factors. The largest emissions in Poland 
Table 3 Averaged $\mathrm{CO}_{2}$ emissions per capita from all types of fuels used in the residential sector, except for biomass (Poland, 2010, Mg)

\begin{tabular}{|c|c|c|}
\hline \multirow[t]{2}{*}{ Category of territory } & \multicolumn{2}{|c|}{ Averaged $\mathrm{CO}_{2}$ emissions per capita $(\mathrm{Mg})$} \\
\hline & $\begin{array}{l}\text { EDGAR results within } \\
\text { administrative boundaries } \\
\text { of territories }\end{array}$ & $\begin{array}{l}\text { GESAPU results (polygons } \\
\text { aggregated to administrative } \\
\text { boundaries of territories) }\end{array}$ \\
\hline $\begin{array}{l}\text { Highly urbanized territories } \\
\text { (18 cities with more than } 200,000 \text { inhabitants) }\end{array}$ & 0.761 & 0.429 \\
\hline Urban municipalities (307) & 0.969 & 0.632 \\
\hline Urban-rural municipalities (588) & 1.475 & 1.807 \\
\hline Rural municipalities (1584) & 2.480 & 2.806 \\
\hline
\end{tabular}

are caused by coal (Fig. 10a), which again emphasizes the significant dependence of the national economy on this type of fuel.

\section{Calculation of uncertainty}

As the results of the spatial inventory in the residential sector are based on a set of input parameters that are not certain, it is important to report the uncertainty in our estimates. There are two common approaches to estimating uncertainty-error propagation and the Monte Carlo method. The first method is used in cases where the input values are small and normally distributed. As our input data are characterized by normal or log-normal distributions, we use Monte Carlo methods to evaluate uncertainty intervals.

There are three main sources of uncertainty when estimating GHG emissions in the residential sector at the regional level: uncertainty in the statistical data (normal distribution, 95\% confidence interval), calorific values (normal distribution, $95 \%$ confidence interval), and emission factors $\left(\mathrm{CO}_{2}\right.$-normal distribution, $\mathrm{CH}_{4}$ and $\mathrm{N}_{2} \mathrm{O}$ - log-normal distribution; $95 \%$ confidence interval). The quality of the statistical data and therefore its uncertainty usually depends on the sector of activity and on how well developed the statistical reporting system is. According to IPCC, countries with better developed statistical systems account for around $4 \%$ of uncertainty (e.g., Poland), while in other countries with $10 \%$ or more uncertainty (e.g., Ukraine), the values are normally distributed. The second source of uncertainty is calorific values, which are used to convert the amount of fuel to energy units. These values are normally distributed, and the uncertainty ranges differ for different energy sources.

In order to combine all sources of uncertainty, we used a Monte Carlo method to sample random variables from normal and log-normal distributions. The implementation of the method is done using the $\mathrm{R}$ statistical package. We considered a $95 \%$ confidence interval for estimating uncertainty in the emissions. We assessed the uncertainty at the regional level as most of the data about energy consumption are disaggregated from this level downwards.

Based on the results obtained, the highest absolute uncertainties are found in the Mazowian region (MAZ) followed by the Great Poland (WKP) and Silesian (SLK) regions (Fig. 11). The relative uncertainties are similar across the regions and are between 12.4 and $18.0 \%$. As the main energy source in Ukraine is natural gas, the absolute uncertainties are smaller than in Poland. The highest absolute uncertainties are in Donetsk (DT), Dnipropetrovsk (DP), Kyiv (KV), and Lviv (LV) regions (Fig. 12). The relative 


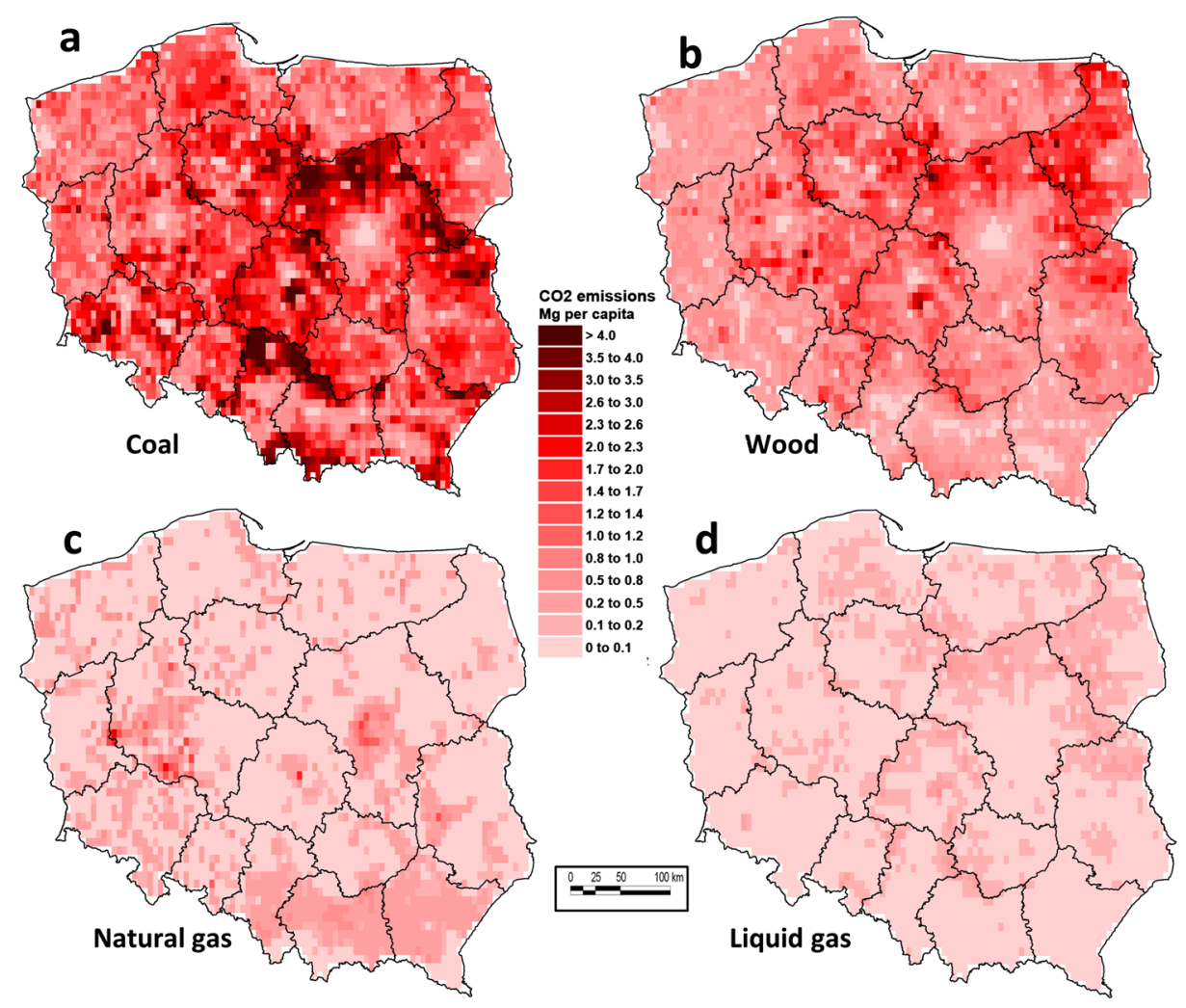

Fig. 10 Shares of GHG emissions from the main types of fuel used in the residential sector in Poland (GESAPU results aggregated to EDGAR grid; 2010)

uncertainty ranges are similar in all the regions, and are about $11.5 \%$ for the lower range of the uncertainty interval and below $11.7 \%$ for the upper range. In Ukraine, the uncertainty of emissions from burning coal in the residential sector is between 19.9 and $22.8 \%$, natural gas -11.4 to $11.7 \%$, and biomass -53.6 to $88.8 \%$, while in Poland, the uncertainty of GHG emissions in $\mathrm{CO}_{2}$-equivalent from burning coal is between 19.3 and to $22.2 \%$, natural gas-around $4.4 \%$, and biomass -51.5 to $81.3 \%$.

\section{Discussion and conclusions}

In this study we presented a method for estimating GHG emissions in the residential sector at a high spatial resolution. As our approach is generic, it can be applied to other countries and further adapted when different statistical and spatial data are available and for different levels of aggregation. We demonstrated that the approach can be applied to two countries with different statistical information and population density maps. A comparison of results in the bordering regions between the two countries shows that specific emissions are at the same level in both regions as they have similar population densities, climate conditions, and energy demand. 


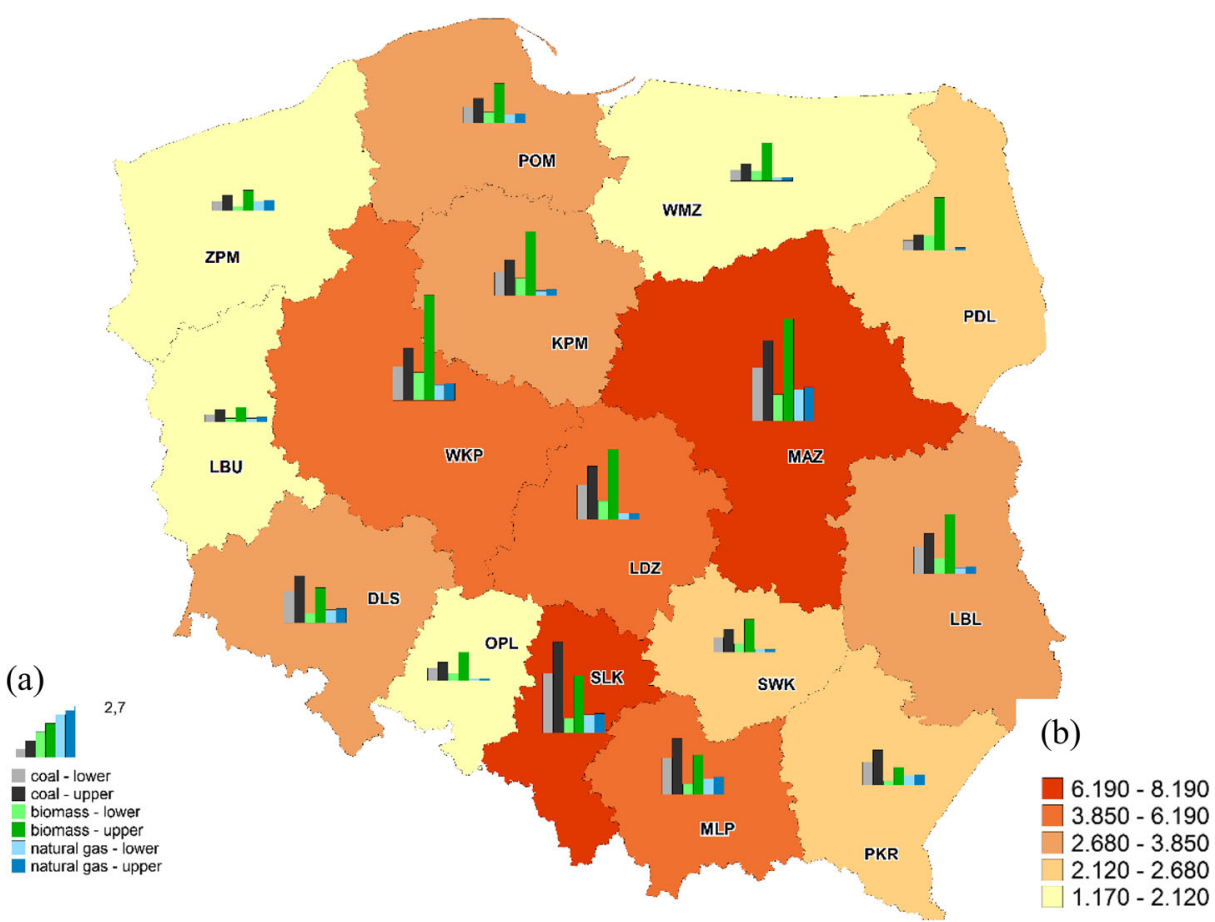

Fig. 11 Uncertainty of $\mathrm{GHG}$ emissions in $\mathrm{CO}_{2}$-equivalent for the main energy sources used in the residential sector in Poland. Bars - upper and lower ranges of GHG emissions from burning different fuels, $\mathrm{Tg}, \mathrm{CO}_{2}$-eq, 2010 (a). Total GHG emissions from burning coal, natural gas, and biomass at the regional level in $\mathrm{CO}_{2}$-eq, $\mathrm{Gg}$, 2010 (b)

Because population is the most important proxy in our approach, we decided to use population density maps rather than other free spatial data, such as that collected by crowdsourced initiatives such as OpenStreetMap (Mooney and Minghini 2017). Such crowdsourced data sets are available at a more detailed level but are usually incomplete. Even if they were available and complete for a particular country of interest, the approach developed here for this level of disaggregation would not be easily transferable to other geographical regions where spatial data may be missing. In contrast, settlement maps and population data exist for most countries. Therefore, the method developed here could potentially be applied to a larger area with some minor modifications accounting for regional specifics and the availability of statistical data.

In contrast to other approaches where proxy data are used to disaggregate GHG emissions, our method provides estimates of emissions at the elementary object level. Such results can be used as additional information for pollution estimates and can be linked to the output from other models, e.g., Amann et al. (2011), to obtain additional insights on the spatial emission structure. In combination with other results from the GESAPU project, the results can be used as a proxy in other approaches, such as those based on inverse modeling or nighttime lights data, to obtain the structure of emissions by sectors.

Spatial estimates of GHG emissions can be useful to support policy decisions focused on emission reductions in different regions. Furthermore, the knowledge of the spatial distribution can help to determine the contribution of individual communities to the total emissions of the country. Moreover, it can provide information to policymakers in what areas to prioritize 


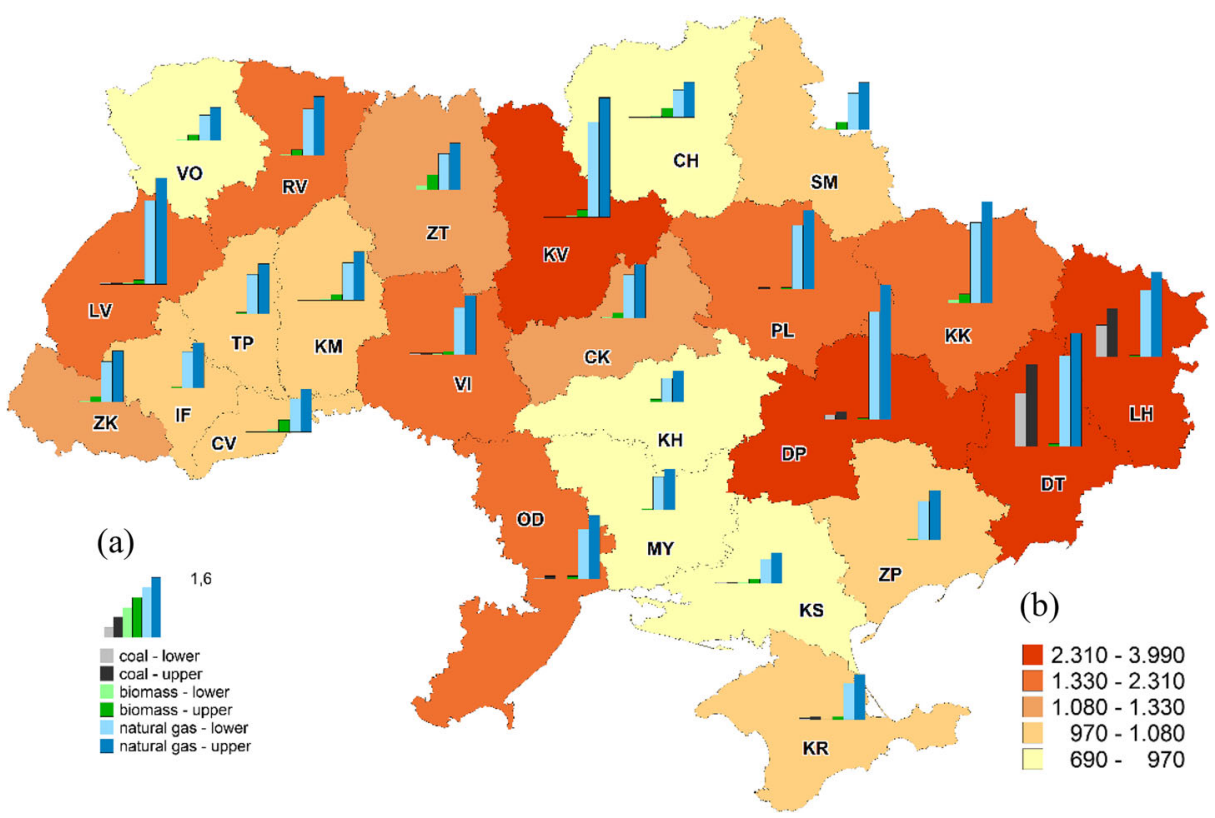

Fig. 12 Uncertainty of GHG emissions in $\mathrm{CO}_{2}$-equivalent for the main energy sources used in the residential sector in Ukraine. Bars - upper and lower ranges of GHG emissions from burning different fuels, $\mathrm{Tg}, \mathrm{CO}_{2}$-eq, 2010 (a). Total GHG emissions from burning coal, natural gas, and biomass at the regional level in $\mathrm{CO}_{2}$-eq, $\mathrm{Gg}$, Q8 2010 (b)

interventions that could stimulate energy efficiency investments in buildings. Dissemination of these results to local communities may raise the awareness of citizens regarding their GHG emission footprint and initiate a discussion of possible emission reduction strategies at the local level.

Acknowledgements The study was conducted within the European Union FP7 Marie Curie Actions IRSES project no. 247645, acronym GESAPU.

Funding Information Open access funding provided by International Institute for Applied Systems Analysis (IIASA).

Open Access This article is distributed under the terms of the Creative Commons Attribution 4.0 International License (http://creativecommons.org/licenses/by/4.0/), which permits unrestricted use, distribution, and reproduction in any medium, provided you give appropriate credit to the original author(s) and the source, provide a link to the Creative Commons license, and indicate if changes were made.

\section{References}

Ahmad S, Baiocchi G, Creutzig F (2015) $\mathrm{CO}_{2}$ emissions from direct energy use of urban households in India. Environ Sci Technol 49:11312-11320. https://doi.org/10.1021/es505814g

Amann M, Bertok I, Borken-Kleefeld J, Cofala J, Heyes C, Höglund-Isaksson L et al (2011) Cost-effective control of air quality and greenhouse gases in Europe: modeling and policy applications. Environ Model Softw 26(12):1489-1501

Andres RJ, Boden TA, Marland G (2009) Annual fossil-fuel $\mathrm{CO}_{2}$ emissions: mass of emissions gridded by one degree latitude by one degree longitude. Carbon Dioxide Information Analysis Center. https://doi. org/10.3334/CDIAC/ffe.ndp058.2009 
Bai X, Dawson RJ, Ürge-Vorsatz D, Delgado GC, Salisu Barau A, Dhakal S, Dodman D, Leonardsen L, MassonDelmotte V, Roberts DC, Schultz S (2018) Six research priorities for cities and climate change. Nature 555: 23-25. https://doi.org/10.1038/d41586-018-02409-z

BDL (2016) Bank Danych Lokalnych (Local Data Bank), GUS, Warsaw, Poland Available at: http://statgovpl/bdl. Cited 25 Jul 2017

Boychuk P, Boychuk K, Nahorski Z, Horabik J (2012) Spatial inventory of greenhouse gas emissions from the road transport in Poland. ECONTECHMOD: An International Quarterly Journal on Economics of Technology and Modelling Processes 1:9-15

Bun R, Nahorski Z, Horabik-Pyzel J, Danylo O, See L, Charkovska N, Topylko P, Halushchak M, Lesiv M, Valakh M, Kinakh V (2018) Development of a high-resolution spatial inventory of greenhouse gas emissions for Poland from stationary and mobile sources. Mitig Adapt Strateg Gob Chang. https://doi.org/10.1007 /s11027-018-9791-2

Cai B, Li W, Dhakal S, Wang J (2018) Source data supported high resolution carbon emissions inventory for urban areas of the Beijing-Tianjin-Hebei region: spatial patterns, decomposition and policy implications. J Environ Manag 206:786-799. https://doi.org/10.1016/j.jenvman.2017.11.038

Charkovska N, Horabik-Pyzel J, Bun R, Danylo O, Nahorski Z, Jonas M, Xiangyang X (2018) High-resolution spatial distribution and associated uncertainties of greenhouse gas emissions from the agricultural sector. Mitig Adapt Strateg Glob Chang. https://doi.org/10.1007/s11027-017-9779-3

Danylo O (2015) Mathematical modeling and spatial analysis of greenhouse gas emissions in the residential sector. PhD Thesis, Lviv Polytechnic National University

Defourny P, Boettcher M, Bontemps S, Kirches G, Lamarche C, Peters M, Santoro M, Schlerf M (2016) Land cover cci Product user guide version 2. Technical report, European Space Agency

Denier van der Gon HAC, Bergström R, Fountoukis C et al (2015) Particulate emissions from residential wood combustion in Europe - revised estimates and an evaluation. Atmos Chem Phys 15:6503-6519. https://oi. org/10.5194/acp-15-6503-2015

EEA (2016) Sectoral greenhouse gas emissions by IPCC sector. Available at: https://wwweeaeuropaeu/data-andmaps/daviz/change-of-co2-eq-emissions-2\#tab-dashboard-01. Cited 20 Jul 2018

Eurostat (n.d.) Population. Eurostat database Available at: http://eceuropaeu/eurostat/data/database. Cited 12 Jul 2018

FAO GEONETWORK (2015) Global Administrative Unit Layers (GAUL) (GeoLayer). (Latest update: 04 Jun 2015). Available at: http://data.fao.org/ref/f7e7adb0-88fd-11da-a88f-000d939bc5d8.html?version=1.0. Cited 29 Jun 2018

Galindo MF, Roger-Lacan C, Gährs U, Aumaitre V (2016) Efficient district heating and cooling systems in the EU - case studies analysis, replicable key success factors and potential policy implications, EUR 28418 EN. https://doi.org/10.2760/371045

Gallego FJ (2010) A population density grid of the European Union. Popul Environ 31:460-473. https://doi. org/10.1007/s11111-010-0108-y

Ghosh T, Elvidge CD, Sutton PC, Baugh KE, Ziskin D, Tuttle BT (2010) Creating a global grid of distributed fossil fuel $\mathrm{CO}_{2}$ emissions from nighttime satellite imagery. Energies 3:1895-1913. https://doi.org/10.3390 /en3121895

GUS (2017) Główny Urząd Statystyczny (Central Statistical Office of Poland). Available at: http://statgovpl/en/. Cited 10 Dec 2017

Haylock MR, Hofstra N, Klein Tank AMG et al (2008) A European daily high-resolution gridded data set of surface temperature and precipitation for 1950-2006. J Geophys Res 113:D20119. https://doi.org/10.1029 /2008JD010201

Hogue S, Roten D, Marland E, Marland G, Boden TA (2017) Gridded estimates of $\mathrm{CO}_{2}$ emissions: uncertainty as a function of grid size. Mitig Adapt Strateg Glob Chang. https://doi.org/10.1007/s11027-017-9770-z

IPCC (2006) IPCC guidelines for national greenhouse gas inventories, prepared by the National Greenhouse Gas Inventories Programme. In: Eggleston HS, Buendia L, Miwa K, Ngara T, Tanabe K (eds). Available at: https://www.ipcc-nggip.iges.or.jp/public/2006gl/. Cited $10 \mathrm{Feb} 2018$

IPCC (2014) Summary for policymakers. In: Climate change 2014: impacts, adaptation, and vulnerability. Part A: global and sectoral aspects. Contribution of working group II to the fifth assessment report of the intergovernmental panel on climate change. In: Field, CB, Barros VR, Dokken DJ, Mach KJ, Mastrandrea MD, Bilir TE, Chatterjee M, Ebi KL, Estrada YO, Genova RC, Girma B, Kissel ES, Levy AN, MacCracken S, Mastrandrea PR, White LL (eds). Cambridge University Press, Cambridge, pp 1-32

Janssens-Maenhout G, Crippa M, Guizzardi D et al (2017) EDGAR v4.3.2 Global Atlas of the three major Greenhouse Gas Emissions for the period 1970-2012. Earth Syst Sci Data Discuss:1-55. https://oi. org/10.5194/essd-2017-79 
Jones C, Kammen DM (2014) Spatial distribution of U.S. household carbon footprints reveals suburbanization undermines greenhouse gas benefits of urban population density. Environ Sci Technol 48:895-902. https://doi.org/10.1021/es4034364

Kuenen JJP, Visschedijk AJH, Jozwicka M, Denier Van Der Gon HAC (2014) TNO-MACC_II emission inventory; a multi-year (2003-2009) consistent high-resolution European emission inventory for air quality modelling. Atmospheric Chemistry and Physics 14(20):10963-10976

Lee S, Lee B (2014) The influence of urban form on GHG emissions in the U.S. household sector. Energ Policy 68:534-549. https://doi.org/10.1016/j.enpol.2014.01.024

Levine M, Ürge-Vorsatz D, Blok K et al (2007) 2007 residential and commercial buildings. In: Metz B, Davidson OR, Bosch PR, Dave R, Meyer LA (eds) Climate change 2007: mitigation. Contribution of working group III to the fourth assessment report of the intergovernmental panel on climate change. Cambridge University Press, Cambridge. Available at: https://www.ipcc.ch/pdf/assessment-report/ar4/wg3/ar4-wg3-chapter6.pdf. Cited 17 Mar 2018

Liu J, Mauzerall DL, Chen Q, Zhang Q, Song Y, Peng W, Klimont Z, Qiu X, Zhang S, Hu M, Lin W, Smith KR, Zhu T (2016) Air pollutant emissions from Chinese households: a major and underappreciated ambient pollution source. Proc Natl Acad Sci U S A 113:7756-7761. https://doi.org/10.1073/pnas.1604537113

Miehe R, Scheumann R, Jones CM, Kammen DM, Finkbeiner M (2016) Regional carbon footprints of households: a German case study. Environ Dev Sustain 18:577-591. https://doi.org/10.1007/s10668-0159649-7

Mooney P, Minghini M (2017) A review of OpenStreetMap data. In: Foody GM, See L, Fritz S et al (eds) Mapping and the citizen sensor. Ubiquity Press, London, pp 37-59

Myhre G, Shindell D, Bréon F-M et al (2013) Anthropogenic and natural radiative forcing. In: Stocker TF, Qin D, Plattner G-K et al (eds) Climate Change 2013: the physical science basis. Contribution of working group I to the fifth assessment report of the intergovernmental panel on climate change. Cambridge University Press, Cambridge

Nejat P, Jomehzadeh F, Taheri MM, Gohari M, Abd. Majid MZ (2015) A global review of energy consumption, $\mathrm{CO} 2$ emissions and policy in the residential sector (with an overview of the top ten CO2 emitting countries). Renew Sust Energ Rev 43:843-862. https://doi.org/10.1016/j.rser.2014.11.066

NIR (2012a) Poland's national inventory report 2012, KOBIZE, Warsaw, 2012, 358 p Available at: http://unfeccint/national_reports. Cited 19 Oct 2017

NIR (2012b) National inventory of anthropogenic emissions by sources and removals by sinks of greenhouse gases in Ukraine for 1990-2010, Kyiv, 2012, 728 p. Available at: http://unfcccint/national_reports. Cited 25 Oct 2017

Oda T, Maksyutov S (2011) A very high-resolution $(1 \mathrm{~km} \times 1 \mathrm{~km})$ global fossil fuel $\mathrm{CO} 2$ emission inventory derived using a point source database and satellite observations of nighttime lights. Atmos Chem Phys 11: 543-556. https://doi.org/10.5194/acp-11-543-2011

Oda T, Maksyutov S, Andres RJ (2018) The open-source data inventory for anthropogenic CO2, version 2016 (ODIAC2016): a global monthly fossil fuel CO2; gridded emissions data product for tracer transport simulations and surface flux inversions. Earth Syst Sci Data 10:87-107. https://doi.org/10.5194/essd-10$87-2018$

OECD/IEA (2014) CO2 emissions from residential buildings and commercial and public services (\% of total fuel combustion). Available at: https://dataworldbankorg/indicator/ENCO2BLDGZS?locations=PL-UA\&view= chart. Cited 20 May 2018

Patarasuk R, Gurney KR, O’Keeffe D, Song Y, Huang J, Rao P, Buchert M, Lin JC, Mendoza D, Ehleringer JR (2016) Urban high-resolution fossil fuel $\mathrm{CO}_{2}$ emissions quantification and exploration of emission drivers for potential policy applications. Urban Ecosyst 19:1013-1039. https://doi.org/10.1007 /s11252-016-0553-1

Rayner PJ, Raupach MR, Paget M, Peylin P, Koffi E (2010) A new global gridded data set of CO2 emissions from fossil fuel combustion: methodology and evaluation. J Geophys Res 115. https://doi.org/10.1029/2009 JD013439

Solecki W, Rosenzweig C, Dhakal S, Roberts D, Barau AS, Schultz S, Ürge-Vorsatz D (2018) City transformations in a $1.5{ }^{\circ} \mathrm{C}$ warmer world. Nat Clim Chang 8:177-181. https://doi.org/10.1038 /s41558-018-0101-5

UkrSTAT (2017) State statistics service of Ukraine. Available at: http://wwwukrstatgovua/. Cited 18 Dec 2017

UNFCCC (2016) National inventory submissions 2016. Available at: http://unfeccint/national_reports/annex_i_ ghg_inventories/national_inventories_submissions/items/9492php. Cited 11 Jun 2018

World Bank (2018) Ukraine. Total population. Available at: https://dataworldbankorg/indicator/ SPPOPTOTL ?locations $=$ UA\&view=chart. Cited 27 May 2018

Żurawski J (2008) Energooszczędność w budownictwie. Cz. 2. Energochłonność budynków mieszkalnych. Izolacje 13:22-25 
Publisher's note Springer Nature remains neutral with regard to jurisdictional claims in published maps and institutional affiliations.

\section{Affiliations}

Olha Danylo ${ }^{1,2} \cdot$ Rostyslav Bun ${ }^{2,3} \cdot$ Linda See $^{1} \cdot$ Nadiia Charkovska $^{1}$

1 International Institute for Applied Systems Analysis, A-2361 Laxenburg, Austria

2 Lviv Polytechnic National University, St. Bandery, 12, Lviv 79013, Ukraine

3 WSB University, 41-300 Dąbrowa Górnicza, Poland 